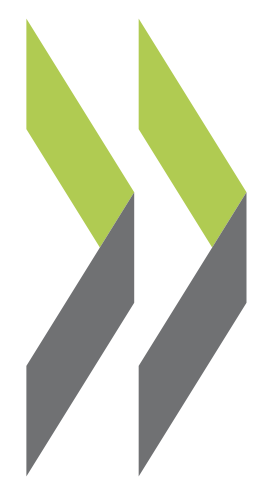

OECD Economics Department Working Papers No. 618

Achieving Sustainability of the Energy Sector Annabelle Mourougane in Canada 
Organisation de Coopération et de Développement Économiques

Organisation for Economic Co-operation and Development

27-Jun-2008

ECONOMICS DEPARTMENT

English - Or. English

\section{ACHIEVING SUSTAINABILITY OF THE ENERGY SECTOR IN CANADA}

ECONOMICS DEPARTMENT WORKING PAPER No. 618

By

Annabelle Mourougane

All OECD Economics Department Working Papers are available on the OECD internet website at www.oecd.org/eco/working_papers

JT03248408

Document complet disponible sur OLIS dans son format d'origine

Complete document available on OLIS in its original format 


\title{
ABSTRACT/RÉSUMÉ
}

\author{
Achieving sustainability of the energy sector in Canada
}

\begin{abstract}
Energy represents a major sustainable-development challenge for Canada. In the short term, labour shortages and infrastructure bottlenecks are likely to hinder energy developments and need to be addressed. In addition, provincial fiscal management could be improved by adopting prudent allocation and withdrawal rules of revenues from non-renewable resources to and from a long-term fund. Eventually the main challenge will be to curb greenhouse gas emissions (GHGs), despite the rapid expansion of high emitting sectors. The effectiveness of environmental policies could be enhanced by better federal-provincial coordination. Efforts should be concentrated on designing and implementing an emissions-trading scheme compatible with corresponding systems abroad. Finally, effective and efficient systems of regulation and taxation are essential to facilitate the timely realisation of energy supply plans.
\end{abstract}

JEL classification: Q4; Q2; H7; H2.

Key words: energy; environment; climate change; Canada; oil sands; GHG emissions; biofuels.

$* * * * *$

Maintenir la viabilité du secteur de l'énergie au Canada

L'énergie représente pour le Canada un défi majeur en termes de développement durable. Dans l'immédiat, il faut remédier aux pénuries de main-d'œuvre et d'infrastructure qui risquent d'entraver la réalisation des projets énergétiques. En outre, on pourrait améliorer la gestion budgétaire provinciale en adoptant des règles prudentes d'allocation et de retrait pour les recettes de ressources non renouvelables affectées à un fonds à long terme. En définitive, le principal défi consistera à réduire les émissions de gaz à effet de serre (GES), en dépit de l'expansion rapide des secteurs gros émetteurs. L'efficacité des politiques environnementales pourrait être renforcée par une meilleure coordination entre l'administration fédérale et les administrations provinciales. Les efforts devraient se focaliser sur la conception et la mise au point d'un système d'échange de droits d'émission compatible avec les mécanismes similaires à l'étranger. Enfin, des systèmes de réglementation et d'imposition efficaces et efficients sont indispensables pour faciliter la réalisation en temps voulu des plans d'approvisionnement en énergie.

JEL classification: Q4; Q2; H7; H2.

Mots clés : énergie; environnement; changement climatique; Canada; sables bitumineux; émissions de gaz à effet de serre (GES); bio-carburants.

\section{Copyright @ ( OECD, 2008. All rights reserved.}

Application for permission to reproduce or translate all, or part of, this material should be made to: Head of Publications Service, OECD, 2 rue André-Pascal, 75775 PARIS CEDEX 16, France. 


\title{
TABLE OF CONTENTS
}

\author{
ACHIEVING SUSTAINABILITY OF THE ENERGY SECTOR IN CANADA …......................................5

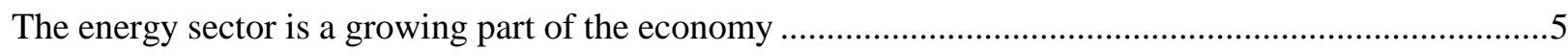 \\ Concerns about the sustainability of current oil-sands developments are growing ................................12 \\ The management of non-renewable resources should be improved .....................................................15

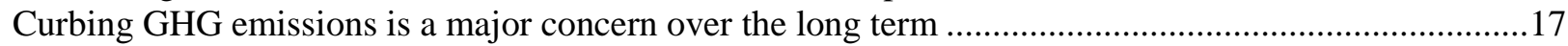

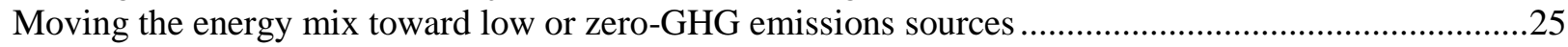

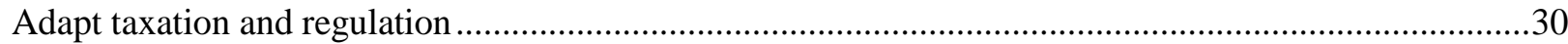

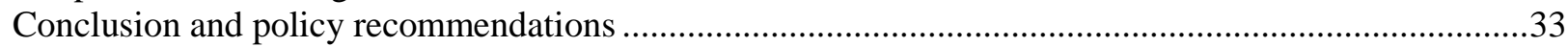

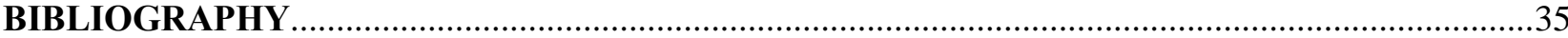

\section{Boxes}

Oil-sands developments .10

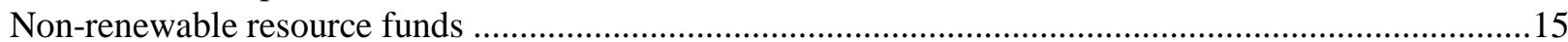

Federal and provincial plans for fighting climate change and air pollution ......................................18

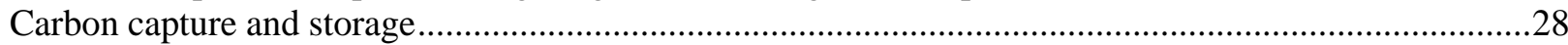

Policy recommendations for energy and environmental policies ..........................................................33

\section{Tables}

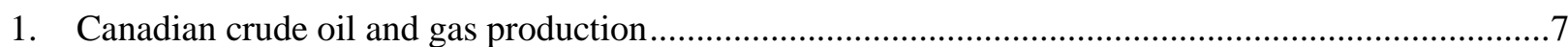

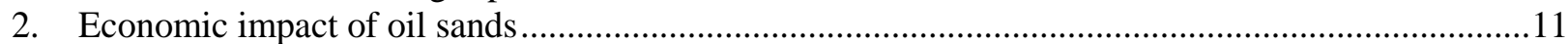

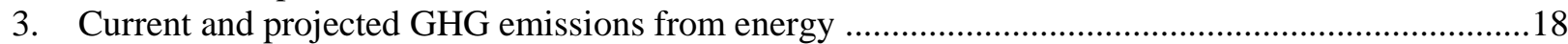

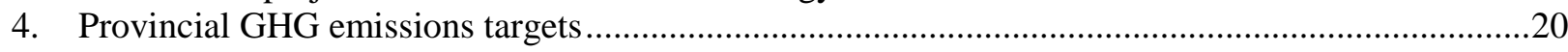

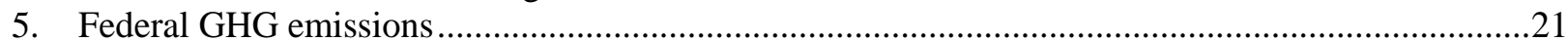

\section{Figures}

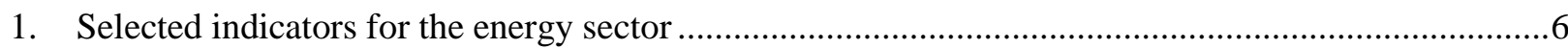

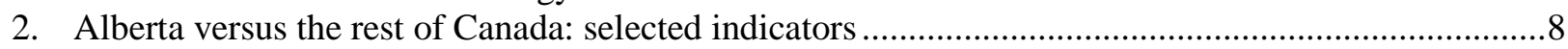

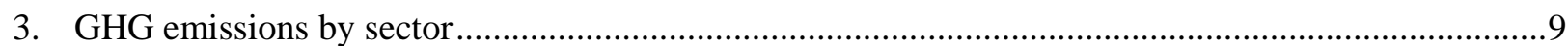

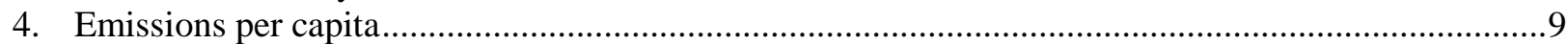

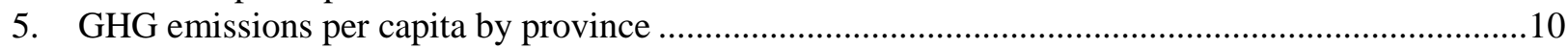

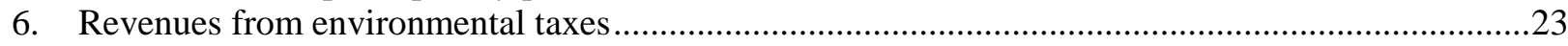

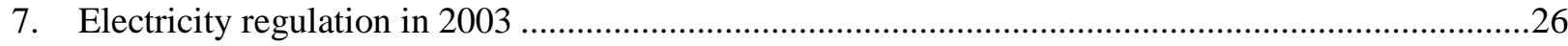


ECO/WKP(2008)26 
ECO/WKP(2008)26

\title{
ACHIEVING SUSTAINABILITY OF THE ENERGY SECTOR IN CANADA
}

\author{
by Annabelle Mourougane ${ }^{1}$
}

Achieving sustainable exploitation of its plentiful energy sources is one of the key challenges Canada will face in the years to come. Indeed, the economy relies considerably on energy-based activities whose development has been encouraged by government policies. At the same time, the production and consumption of energy is responsible for the bulk of the country's greenhouse gas (GHG) emissions. With the rapid development of the western oil sands, emissions are expected to grow significantly. In the context of the growing importance of climate-change issues, both at the national and international levels, and in preparation of post-Kyoto negotiations, it will be important for Canada to exploit its natural resources without excessive costs to the environment. For this purpose, it needs to select near- and long-term development strategies that are economically and socially manageable in current circumstances and can be adjusted over time in light of new information.

This paper analyses the current and future challenges that the energy sector (in particular the oil sands) will face and proposes changes to make development more environmentally and socially sustainable. After a brief overview of the sector, the paper discusses how adjustment to volatile oil prices has triggered boom-bust cycling and how this could be damped. It then examines how the trade-off between energy output and environmental goals in the longer run can be further eased by increased coherence among environmental policy, tax and regulatory frameworks. The last section summarises policy recommendations.

\section{The energy sector is a growing part of the economy}

The energy sector has been expanding at a fast pace since 1998, accounting for almost $10 \%$ of Canada's nominal GDP in 2006 (Figure 1). This growing share is entirely due to very large increases in energy prices, as the growth of real output has been below that of the overall economy. The energy sector is very capital-intensive. Higher prices have boosted profits, and energy-related investments are estimated to have accounted for $29 \%$ of total non-residential investment in 2006, up from $21 \%$ in 1998 (Carrier and Turcotte, 2006). Driven by the oil and gas extraction industry, employment in the sector has increased at a faster pace than in the economy as a whole, implying declining relative labour productivity performance.

Approximately half of Canada's energy sector is foreign-owned ${ }^{2}$ and is strongly focused on export markets. The share of energy exports in nominal GDP almost tripled to 6.0\% from 1998 to 2006. In recent years, the share of energy exports directed to the United States has been increasing with the development of offshore oil, the start of gas exports from Sable Island (off the coast of Nova Scotia) and the opening of the Alliance pipeline connecting Alberta to Chicago. Chapter 6 of the North American Free Trade Agreement (NAFTA) prohibits government intervention in North American energy markets whether in the form of price discrimination or direct disruption of supply channels that would cause Canadian energy

1. Annabelle Mourougane is a Senior Economist at the OECD Economics Department. The paper is part of the OECD Economic Survey of Canada, published in June 2008. The author would like to thank Peter Jarrett, Stéphanie Jamet, Alexandra Bibbee, Yvan Guillemette and Andrew Dean for useful suggestions, as well as the Canadian authorities for helpful comments and discussions. Special thanks are due to Françoise Correia for excellent research support.

2. Canada's energy sector is to a large extent owned by foreigners: $49.1 \%$ of the assets and $55.9 \%$ of the revenues are foreign owned (Baldwin et al., 2006). 
exports to the United States to fall. However, this clause does not impose any restriction on Canadian producers, who are free to choose their customers and the amount of energy they sell (Holden, 2006).

\section{Figure 1. Selected indicators for the energy sector}

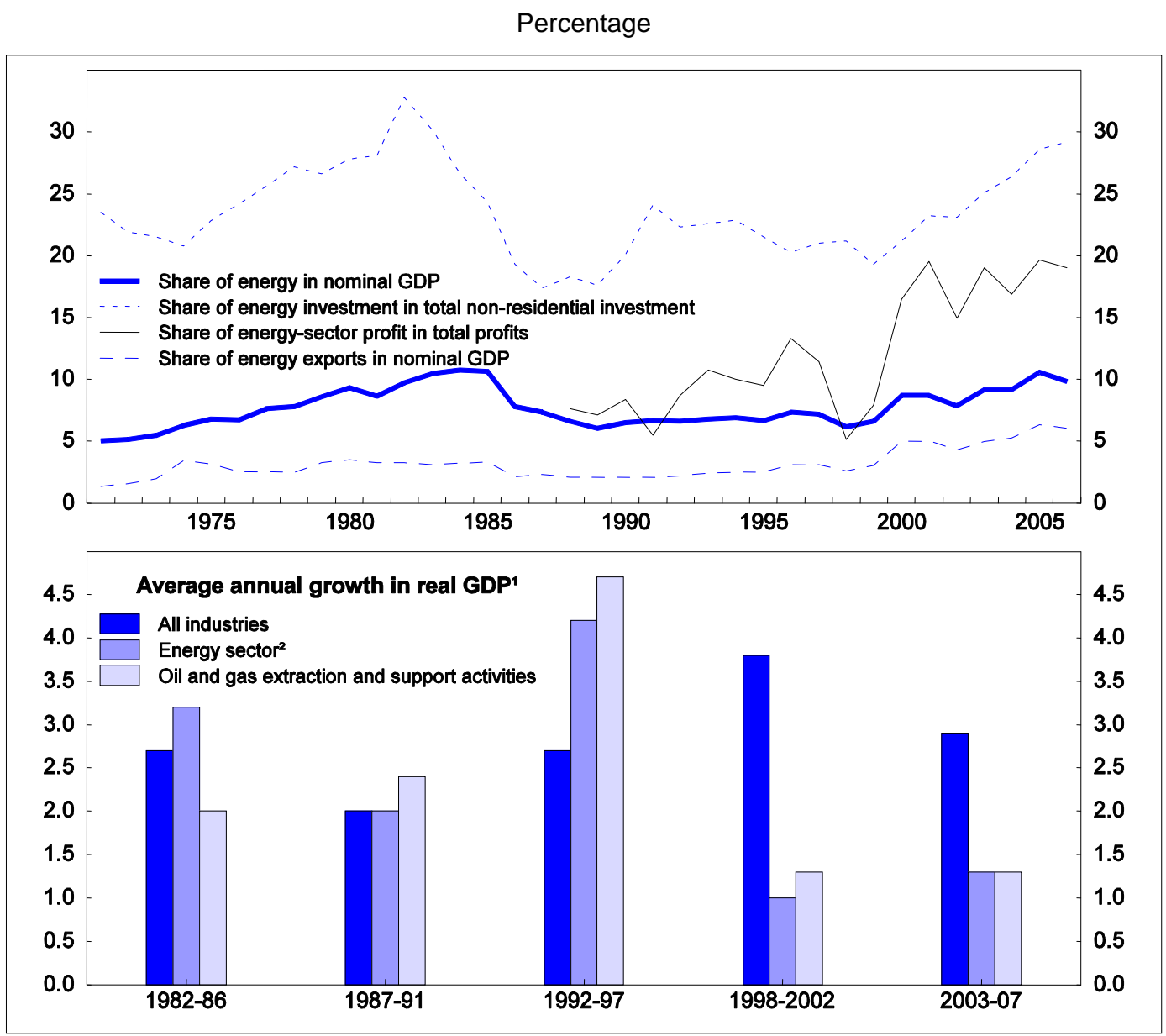

1. Break in series in 1997.

2. The energy sector is composed of oil and gas extraction, coal mining, support activities for mining and oil and gas extraction, electric power generation, transmission and distribution, natural gas distribution, pipeline transportation, petroleum and coal products manufacturing, other metal ore mining.

Source: M. Carrier and J. Turcotte (2006), "The contribution of the energy sector to the Canadian economy", Analytical note, Economic and Fiscal Policy Branch, internal publication of the Department of Finance Canada and Statistics Canada.

Canada has a substantial endowment of diversified energy resources. At the moment it is the eighth-largest producer of crude oil in the world and the second-largest exporter of natural gas after Russia. Canada is well positioned as one of the few countries outside OPEC with significant prospects for production growth: it has the world's second largest proven oil reserves after Saudi Arabia, albeit with considerably higher production costs. Production in the Western Canada Sedimentary Basin - Canada's most important source of crude oil and natural gas - appears to have reached its peak over the last decade. Despite federal and provincial moratoria on exploratory drilling and development of offshore reserves in British Columbia, activity in offshore locations and the Northern territories is being stepped up. It will nonetheless not be sufficient to stave off the decline in traditional oil and gas fields over the long term (Table 1). By contrast, the oil sands, which are mostly located in the province of Alberta, have been developing at a very fast pace (Box 1). The shift within the energy sector from conventional to other 
sources for oil and gas has been facilitated by technological advances and higher world energy prices. ${ }^{3}$ This shift has resulted in increased exploitation costs and lower productivity, despite important technological breakthroughs. Overall, although new extraction methods are currently available to exploit non-conventional sources, further innovations will be needed to ensure sustainable development of the resource.

Table 1. Canadian crude oil and gas production

\begin{tabular}{lrrrr|rrrr}
\hline & \multicolumn{3}{c}{ Thousand barrels per day } & \multicolumn{4}{c}{ Share } \\
\cline { 2 - 8 } & 1990 & 2000 & 2010 & 2020 & 1990 & 2000 & 2010 & 2020 \\
\cline { 2 - 8 } Western Canada & & & & & & & \\
Conventional light and \\
medium
\end{tabular}

Note: Oil sands in situ are recovered by techniques which make the hot bitumen migrate towards producing wells, bringing it to the surface, while the sand is left in place ("in situ" is Latin for "in place").

Source: Canadian Association of Petroleum Producers (2006), 2006-2020 Canadian crude oil production and supply forecasts, Calgary; Canadian Association of Petroleum Producers (2007), Crude oil forecasts, markets and pipeline expansion, Calgary, June; IEA (2007a), International Energy Outlook, Chapter 4, Paris.

Canada also has very large reserves of coal, which is used in electricity generation in some provinces, particularly Alberta. With abundant supply and low price, coal is likely to remain part of the generation mix in the decades ahead, if new clean coal technology improves efficiency and significantly reduces associated GHG emissions through "carbon capture and storage" (see below). Canada is also the world's largest producer of natural uranium. Nuclear energy generation is concentrated in Ontario where most nuclear units are being used to compensate for the phasing-out of coal-fired stations, but new units are in the works in Alberta. In addition, Canada is rich in renewable energy supplies, including hydro power, wind, forest and agricultural biomass and solar potential. The tax treatment of certain renewable energies (e.g. through accelerated capital cost allowances or the ethanol excise tax exemption) has helped support the market entry of these technologies. In addition, renewable energy has also benefited from targeted measures. ${ }^{4}$ Other low or non-GHG emitting sources such as cogeneration, tidal and geothermal electricity

3. In 2004, $42 \%$ of all domestic output came from oil sands, and most of the increase in natural gas production since 2004 has come from coal-based methane (Cross, 2006).

4. This includes the ecoEnergy for Renewable Power programme, a CAD 1.48 billion, 14-year production incentive of $1 \%$ per kilowatt-hour for renewable energy sources (e.g. wind, biomass, small-scale hydro, 
are being developed across the country. A number of liquefied natural gas projects have also been developed in Atlantic Canada.

Figure 2. Alberta versus the rest of Canada: selected indicators

Year-on-year percentage change

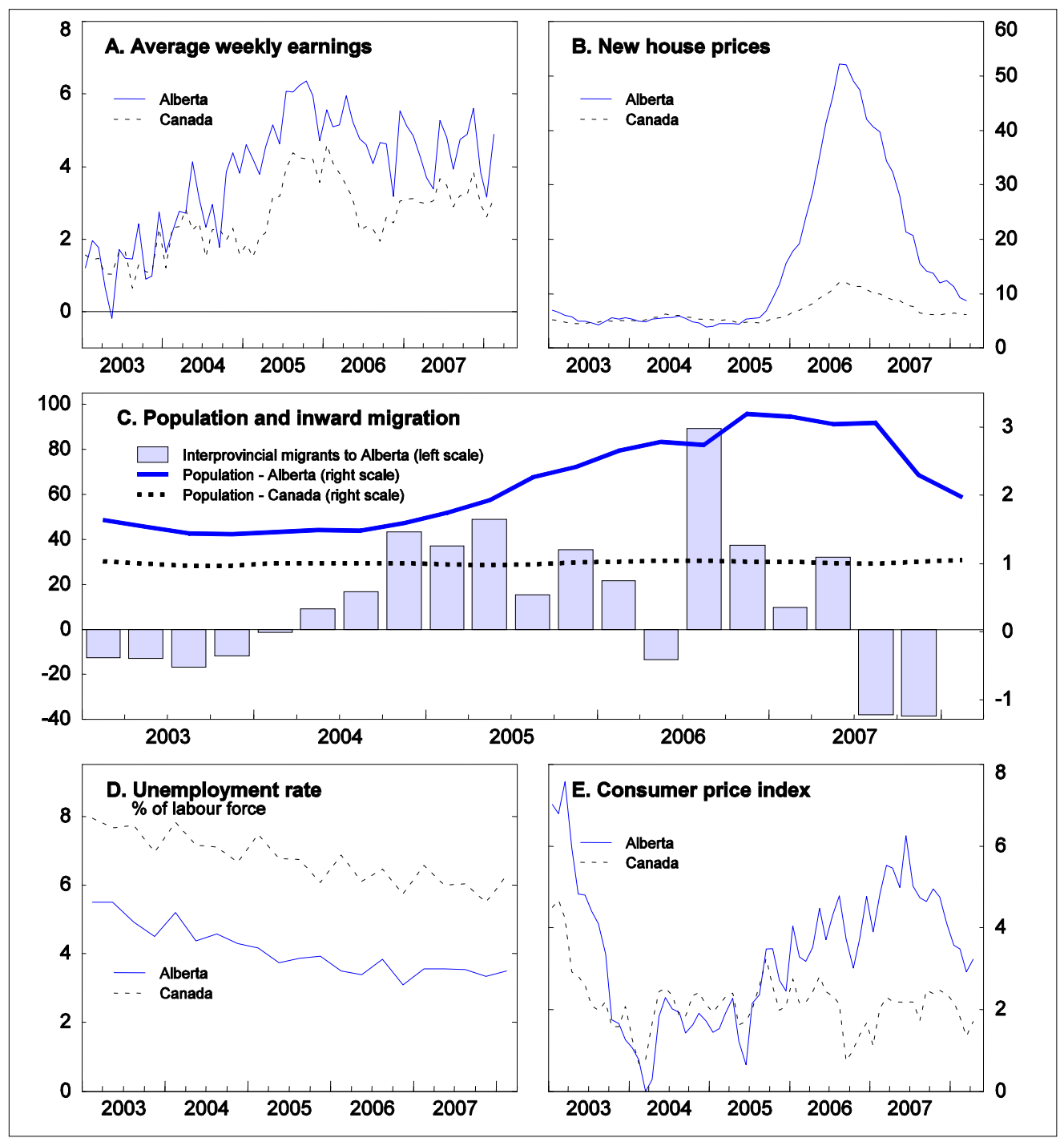

Source: Statistics Canada.

The regional distribution of energy production is quite uneven, with Alberta and to a lesser extent British Colombia, Saskatchewan and Newfoundland and Labrador accounting for the bulk of primary energy production. Differences in resource endowment have generated regional disparities, and the rise in oil prices has benefited mostly western provinces. The economy in the province of Alberta has been overheating (see OECD, 2008b), with the highest inflation in the nation, unemployment at an all-time low and workers being brought in from elsewhere (Figure 2). By contrast, the increase in commodity prices has

solar photovoltaic, geothermal, tidal and wave) which is expected to increase renewable electricity capacity by 4000 megawatts. 
generated a marked appreciation of the Canadian dollar and hit manufacturing-based provinces such as Ontario and Quebec, which also have to compete with emerging Asian economies.

\section{Figure 3. GHG emissions by sector}

2005 , as a percentage of total

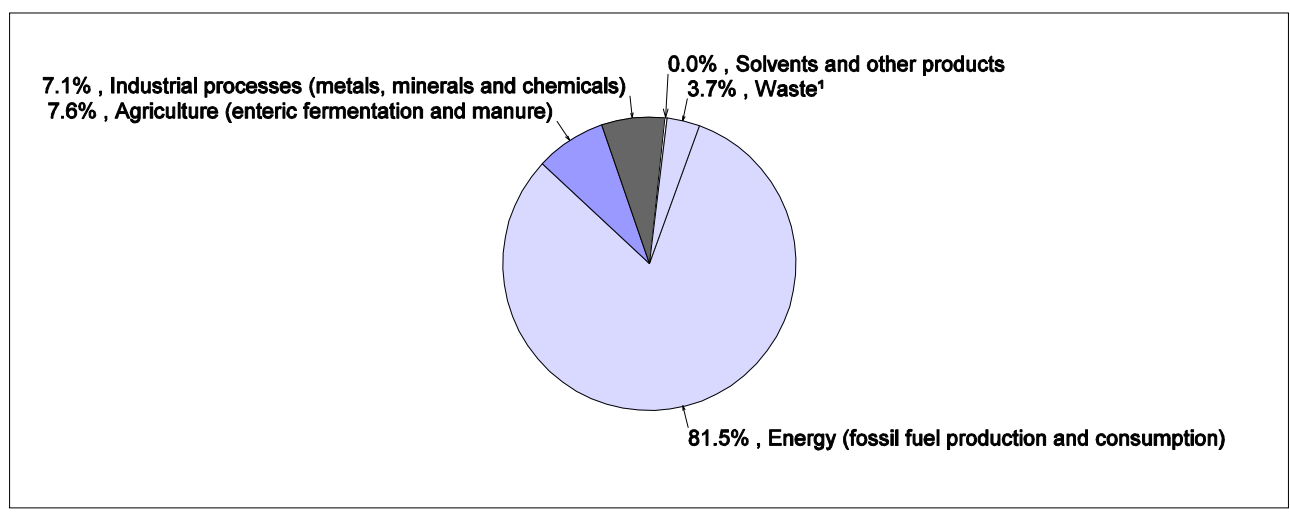

1. Solid waste disposal, wastewater handling, waste incineration.

Source: Environment Canada (2007), National Inventory Report, 1990-2005, Greenhouse Gas Sources and Sinks in Canada, April.

The energy sector is the largest contributor to total GHG emissions in Canada (Figure 3). The country produces over $2 \%$ of global emissions, i.e. more emissions per capita than virtually any other country (figure 4). Canada's emissions are also growing faster than in most other industrialised countries: emissions have been rising primarily as a result of an increasing population, economic growth and expanding fossil-fuel production (Environment Canada, 2007a). ${ }^{5}$ The distribution of national emissions is highly skewed to certain provinces and will become increasingly so in the future (Figure 5). Indeed, emissions are disproportionately concentrated in provinces that host most of the country's energy industry, particularly the emissions-intensive oil sands. As a result, associated adjustment costs to curb emissions will be borne unevenly across the provincial landscape.

\section{Figure 4. Emissions per capita}

Tonnes of $\mathrm{CO}_{2}$ per capita

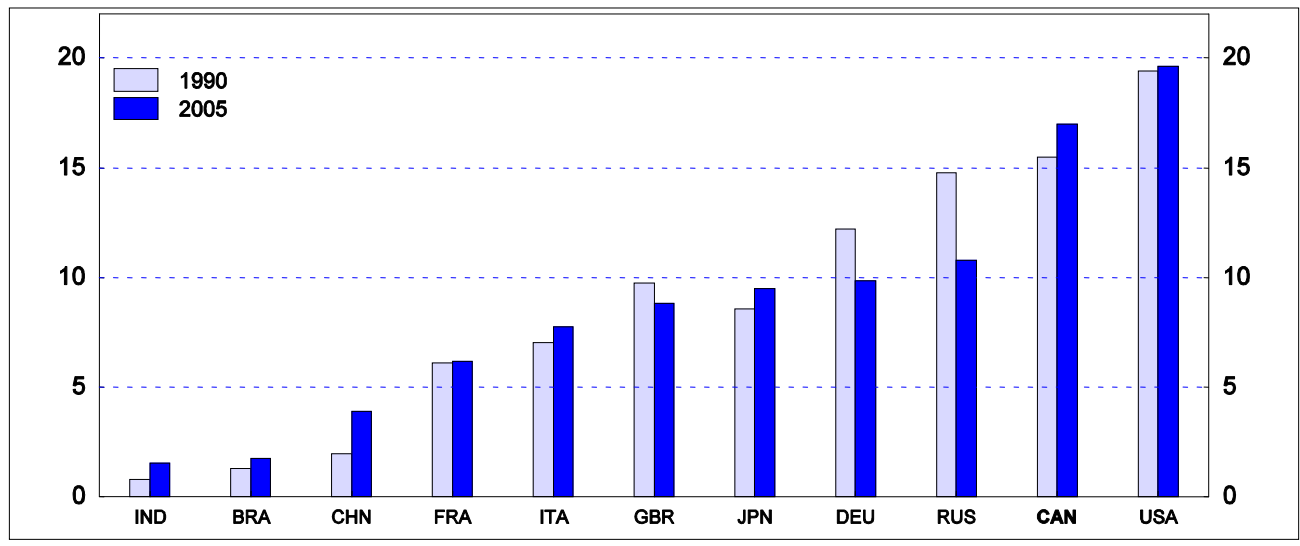

Source: International Energy Agency, $\mathrm{CO}_{2}$ emissions from fuel combustion, 1971-2005, Paris, 2007 Edition.

5. Even without the emissions resulting from oil sands, emissions per capita would be greater than anywhere (except the United States). 
Climate change is a very topical issue in Canada, and views differ as to the appropriate objective to pursue. The federal government has recently released its final regulatory framework for industrial greenhouse gas emissions, which elaborates its April 2007 Regulatory Framework for Air Emissions. At the moment, Canada is currently emitting some 33\% above its Kyoto target. The lack of political willingness to meet the Kyoto target has been criticized within the country and in the international scene. Still, the focus of environmental policies is now mostly on preparing for the post-Kyoto period.

\section{Figure 5. GHG emissions per capita by province}

Tonnes of $\mathrm{CO}_{2}$ equivalent per capita

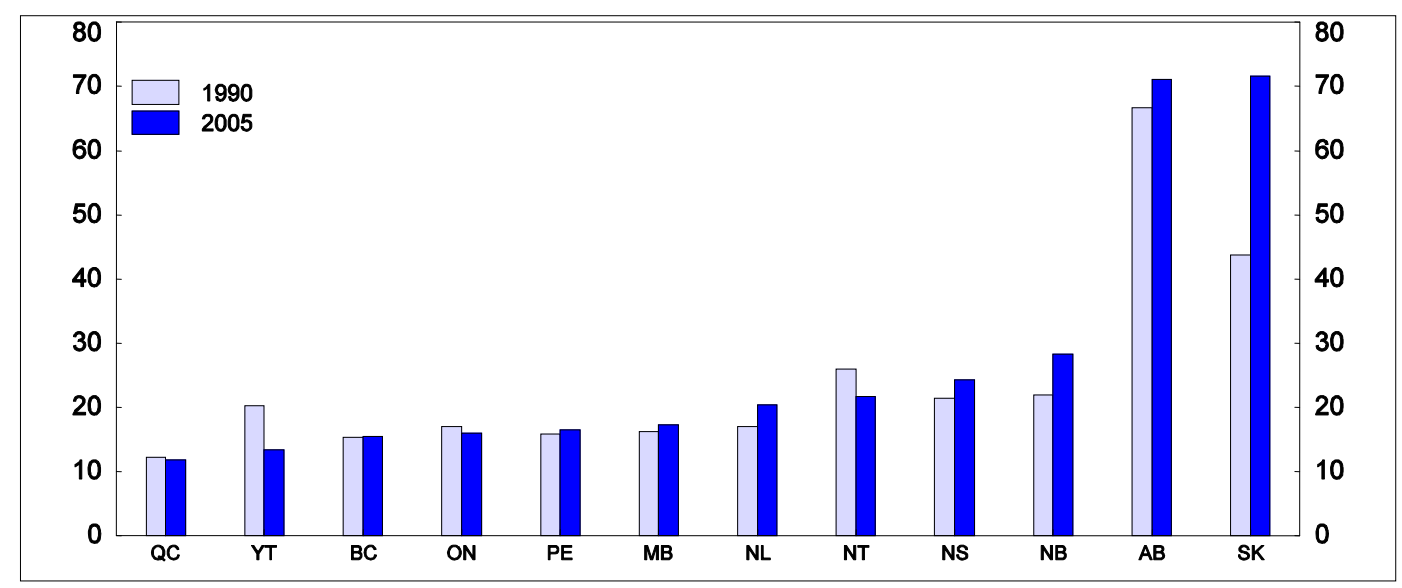

Source: Environment Canada (2007), National Inventory Report, 1990-2005, Greenhouse Gas Sources and Sinks in Canada, April.

\section{Box 1. Oil-sands developments}

Oil sands are deposits of bitumen, a heavy black viscous oil that must be treated to convert it into an upgraded crude oil before it can be used by refineries to produce gasoline and diesel fuel. The bitumen obtained through either mining or in situ production methods can be used directly for asphalt, diluted and transported by pipeline to refineries for processing, or upgraded into synthetic crude oil (SCO). SCO itself is a feedstock for refineries, where it can be further processed into gasoline, aviation fuel or other products.

\section{Reserves}

In December 2002, the Oil \& Gas Journal reported that Canada ranked second in terms of global proven crude oil reserves (15\% of world reserves), after Saudi Arabia. The majority of these reserves are found in Alberta's oil sands. Under anticipated economic conditions and using current technology, Alberta has approximately 176 billion barrels (bbls) of proven oil reserves (174 billion bbls of crude bitumen, 1.6 billion bbls of crude oil). While conventional oil reservoirs are scattered throughout the province, oil sands underlie 140200 square kilometers of land primarily in northern Alberta. There are over 3100 oil sands agreements with the province totalling approximately 48973 square kilometers. Close to $65 \%$ of possible oil sands areas are still available for exploration and leasing.

\section{Cost and extraction}

Producers have focused on improving efficiency and adopting new technology to lower production costs. Operating costs to produce a barrel of oil from bitumen averaged about CAD 18 per barrel in 2004 but have since risen sharply. There are several technologies to extract oil sands bitumen, and all require enormous amounts of energy (often natural gas) and water. Mining operations extract bitumen from reserves close to the surface. For oil deeper underground, processes such as Steam-Assisted Gravity Drainage and Cyclic Steam Stimulation are used. The rise in natural gas prices in 2005-06 prompted development of new extraction and processing methods that do not require natural gas, but these methods remain costly and need to be tested on a commercial scale. 


\section{Oil-sands royalties and tenure}

Alberta's oil-sands royalty system was specifically designed to encourage development of the resource and takes into account technological risks and capital costs faced by oil-sands developers. A new system was introduced in late 2007 and will be effective in 2009. Under the new system, the royalty base rate will start at $1 \%$ and increase for every dollar oil is priced above CAD 55 per barrel, to a maximum of $9 \%$ when oil is priced at CAD 120 or higher. The net royalty applied post-payout is currently $25 \%$. In the future, it will start at $25 \%$ and increase for every dollar oil is priced above CAD 55 per barrel to $40 \%$ when oil is priced at CAD 120 or higher.

The provincial government owns $97 \%$ of Alberta's mineral rights. They are administered by its Department of Energy. The remaining $3 \%$ are 'freehold' mineral rights owned by individuals and companies and other Crown land held by the federal Government on behalf of First Nations or in national parks. Public offerings or sales of Crown mineral rights are scheduled to be held every two weeks. Oil-sands rights are issued as leases or permits through a competitive bidding system. The highest bidder wins the right to "drill for, win, work, recover and remove" minerals that are owned by the Crown. Water use in the oil-sands area is regulated through a system of licensing and monitoring.

\section{Economic impact of the oil sands}

The expansion of oil-sands production is expected to have a beneficial impact on the Canadian economy. The potential gains in export revenues have resulted in upward pressure on the exchange rate.

Table 2. Economic impact of oil sands

\begin{tabular}{lrrr|c}
\hline & 2006 & 2011 & 2020 & 2006 \\
\cline { 2 - 5 } & \multicolumn{3}{c|}{ CAD billion } & $\begin{array}{c}\text { \% of 2006 } \\
\text { national GDP }\end{array}$ \\
\cline { 2 - 5 } GDP & 44 & 69 & 104 & 3.0 \\
Total & 32 & 49 & 77 & 2.2 \\
Alberta & 7 & 11 & 14 & 0.5 \\
Rest of Canada & 5 & 9 & 13 & 0.3 \\
Rest of the world & 5 & & \\
\hline
\end{tabular}

Source: CERI (2006), Economic Impact of Oil Sands in the Short Term, December, Calgary.

The impact of oil-sands developments on GDP will depend to a large extent on the level of the oil price and the oil-natural gas price differential, which affects the profitability of exploitation. Overall, the impact is estimated to be relatively limited for Canada as a whole (Table 2). Bayoumi and Mülheisen (2006) point to an even smaller impact, with higher oil production lifting Canada's real GDP by $1.1 \%$ in 2020 . Oil-sands activity is expected to become an increasing share of Alberta's total GDP and to represent about 20\% of Alberta's GDP by 2011 (as against 15\% in 2006). Almost half of the employment generated from Alberta's oil sands is expected to occur outside the province (CERI, 2006; Conference Board of Canada, 2007).

Revenues in the form of royalty payments and income taxes from the oil and gas industry vary by province, with Alberta receiving most of them. But the federal Government and other provinces are also expected to benefit from Alberta's energy resource development.Environmental impact of oil sands.

Oil-sands facilities were responsible for $12 \%$ of Alberta's total greenhouse gas emissions in 2006, with Alberta accounting for about a third of Canada's total.

Besides their climate-change effects, the oil sands are generating large and mounting environmental costs in several areas: added demand for water and natural gas (use of between one and three barrels of water per barrel of oil extracted); the accumulation of waste; destruction of delicate boreal ecosystems; and air pollution in the form of acid rain. Oil-sands developments are also reported to be responsible for the declines in a number of fur-bearing mammals (including caribou) and some forest birds throughout Northern Alberta.

Source: Government of Alberta (2006a), Holroyd et al. (2007), Environment Canada's estimates. 


\section{Concerns about the sustainability of current oil-sands developments are growing}

The exploitation of Canada's oil sands is expected to continue expanding rapidly, but the rate of development will depend on the balance between multiple opposing forces. High expected oil prices, geopolitical concerns, the size of the available resource base and proximity to the large US market, and potentially other markets, are encouraging developments (NEB, 2006). On the other hand, natural gas costs, the light versus heavy oil-price differential, water usage, and insufficient labour, infrastructure and services are factors that could potentially inhibit the development of the resource. Another force that will moderate oil-sands development is the obligation to meet new federal and provincial regulations for GHGs and air pollutants.

The rapid development of the Alberta's oil-sands industry has generated labour-market bottlenecks and deleterious socio-economic and environmental effects.

\section{Labour shortages}

There is currently a limited supply of skilled workers in Alberta. Wage increases have not been sufficient to attract the needed labour. At the same time, many businesses have had to cut back their hours. The most severe shortages are in the construction sector. Indeed, the construction workforce across Alberta is already at an all time high, and many more workers will be needed to meet planned investment growth in the short term. In addition, neighbouring British Columbia's boom due to construction activity for the 2010 Winter Olympic Games is exacerbating the pressures in Alberta. The boom has also placed pressure on staffing in other sectors, in particular those dominated by small businesses, which have limited revenue streams and cannot compete with wage increases in the oil industry. At the national level, competition for labour has pulled workers from other parts of Canada.

The labour market is expected to remain tight in the coming years and to restrict the pace of expansion. According to an Alberta government forecast, the province will need 400000 more workers by 2015. The challenge for the oil-sands sector is not only to find the right skills to cope with the complexity of the projects being undertaken but also to attract these people to Fort McMurray in the remote Wood Buffalo region, where most of Canada's oil-sands deposits are located.

Both short- and long-term solutions have been proposed to help meet these labour-market needs. The government of Alberta released a 10 year Strategy in January 2006, which includes an Oil Sands Industry Sub-Strategy. It outlines various actions to address Alberta's labour-force challenges and is built around four themes: providing education, career, workplace and labour-market information; attracting immigrants and inter-provincial migrants; developing education and training investment; and enhancing community and work attractiveness. A special focus was put on improving labour-force participation of under-represented groups such as women, the disabled and Aboriginals. The Alberta government has also signed an agreement with the federal authorities that will allow for the targeted entry of temporary foreign workers to meet the urgent skilled-labour needs of key projects in Fort McMurray. Overall, it is estimated that these short-term solutions will not be sufficient to increase the supply of skilled workers enough to match the demand created by the rapid expansion of the oil-sands industry. ${ }^{6}$ Looking forward, the construction boom is not expected to last long. ${ }^{7}$ Oil-sands investment is being heavily concentrated in a short period of time, and following the peak, many workers will be released. It will thus be important to

6. Analysis shows that one quarter of the jobs needed will not be filled unless new strategies are put in place to recruit and train people from every possible socio-demographic group (Government of Alberta, 2006b).

7. About $9 \%$ of persons employed in Alberta were working in the construction sector in 2006. Demand for employment in the construction sector is expected to decrease after 2010 (Construction Sector Council, 2007). 
ensure Alberta's set of policies allows firms to make the most of this market opportunity, mitigates the boom-bust cycle and facilitates adjustment when the construction boom ends.

At the federal level, changes to the Employment Insurance (EI) programme could foster inter-provincial labour mobility and help address regional labour shortages. Canada is unique in adjusting its EI access requirements in response to local labour-market conditions, with higher local unemployment rates leading to reduced requirements for coverage (Van Audenrode et al., 2005). ${ }^{8}$ This can retard economic adjustment by providing an incentive for individuals to remain in regions with poor economic conditions. It is difficult to determine empirically to what extent the existence of EI slows the adjustment process, as labour mobility within Canada is one of the highest in the OECD (Kongsrud and Wanner, 2005). Still, modifying the current parameters of the EI entrance requirements by harmonising the regional treatment would enhance labour mobility even further and facilitate the adjustment process. This change is all the more needed as the country has moved from a prolonged state of high unemployment to one of prevailing labour shortages, and institutions need to be consistent with this structural change.

\section{Socio-economic impacts of the boom}

Host communities and regions benefit from numerous positive socio-economic impacts associated with oil-sands developments, including employment and government revenue. But Alberta's rapid growth gives rise also to negative some socio-economic effects. First, government services such as health care and education are subject to increased pressures, and, more generally, municipal infrastructure lags behind population growth. Second, drug and alcohol abuse has increased, and dependence on non-profit social-service providers has risen. Third, as population has grown, housing prices have skyrocketed across the province, causing a housing crisis in almost every urban area. ${ }^{9}$ However, prices and resale activity have starting cooling down, and, as average incomes have also markedly increased in Alberta, housing affordability i.e. the proportion of median pre-tax household income required to service the cost of an average mortgage, is still lower than in Quebec, Ontario and British Columbia (Holt and Goldbloom, 2007). Fourth, high-school completion and post-graduate education rates, which are already below the national average in Alberta, are being impacted, as students are drawn away from education by high wages for labourer, semi-skilled positions and even service-sector jobs. ${ }^{10}$ Finally, high inflation is pushing businesses in secondary industries to relocate elsewhere, taking high-quality, long-term jobs with them.

The provincial government cut capital and social programme spending during the 1990s with the objective of eliminating public debt. These cuts seriously compromised the province's ability to sustain the boom, and its ability to provide the infrastructure necessary to absorb the population growth that accompanied it. As the boom has increased in strength, the government has embarked upon reinvestment in the provincial infrastructure. ${ }^{11}$ However, these outlays are adding fuel to an already overheated economy,

8. In regions with an unemployment rate of $6.0 \%$ or lower, a person has to work 700 hours to become eligible for EI. At the other end of the scale, in regions with unemployment rates of $13.1 \%$ or greater, a worker needs to work only 420 hours of work. The requirements are higher if the worker is a new entrant or a re-entrant to the labour market.

9. In 2006 measured homelessness in Edmonton increased by 19\%, while in Calgary the number of homeless people had risen by 458\% since 1996 (Parkland Institute, 2007).

10. This adverse effect on human capital has also been observed in countries experiencing an oil boom and is often seen as a symptom of "Dutch disease".

11. In February 2007, the Alberta Government made a commitment to spend CAD 396 million over three years on housing and infrastructure needs in Fort McMurray. Past estimates from industry and community representatives had suggested that approximately CAD 1.2 billion would be required for critical public 
and, as construction costs have soared, the government is paying a premium for building public infrastructure. Public-private partnerships (PPPs) have been used in some Canadian provinces, in particular British Columbia, and the federal government and could be useful to finance new infrastructure investments efficiently, in particular the provision of urban public transport. Indeed, experience from other OECD countries, such as the United Kingdom and Australia, suggests that, in addition to providing a new source of capital and expertise, PPPs can, in some cases, lower the overall cost of production and hasten delivery of infrastructure (OECD, 2007). PPPs also allow the transfer of some risks to the private sector, and overall are reported to lead to more effective risk management. Nonetheless, every effort should be made to define clear a legal and policy framework for PPPs and to ensure that the appropriate capacity within government exists to initiate and manage them (OECD, 2008a).

\section{Environmental and energy challenges}

The development of the oil sands requires significant amounts of natural gas, whose reserves are in decline. ${ }^{12}$ As extraction rates triple, energy input needs will also rise. Meeting those needs through other forms of energy such as coal gasification is problematic due to the significantly higher GHG emissions. Nuclear energy is another option, but at the moment it is expensive and has its own associated risks. ${ }^{13}$ In this context, further sustainable production of oil sands will necessitate significant improvements in technology (see below).

Both mining and underground operations use large volumes of water for extracting bitumen from the oil sands, and the limited available supply of water could be a constraint on future expansion plans. ${ }^{14}$ Despite some recycling, almost all of the water withdrawn for oil sands mining operations ends up in tailings ponds (NEB, 2006). Adequate management of river flows is necessary to ensure ecological sustainability, especially in winter when river flows are low. A number of initiatives have been developed to address these water-supply issues in Alberta. First, in February 2007 Alberta Environment set strict limits on how much water oil-sands developers can remove from the Athabasca River, and additional measures are expected in the coming years. Second, a new Water Conservation and Allocation Policy for Oilfield Injection aims to reduce the use of water for in situ projects. ${ }^{15}$ It will be important to regularly review the impact of these changes, in particular the new allocation process, to see if policies reach their conservation objectives without imposing excessive costs on firms. In particular, it will be helpful to assess how the current system compares to market-based instruments, which would encourage an efficient use of

infrastructure needs in the Wood Buffalo region over the next five years (Athabasca Regional Issues Working Group, 2005).

12. A few years ago the Canadian oil-sands industry used a thousand cubic feet (Mcf) of gas for each barrel of oil produced from oil sands via in situ thermal recovery and another $0.5 \mathrm{Mcf} / \mathrm{barrel}$ for upgrading of bitumen into synthetic crude oil (North America Energy Working Group, 2005).

13. These include high levels of fossil-fuel use in the uranium mining and refining process, the risk of accidents, and storage problems for dangerous by-products including radioactive waste with a half-life of thousands of years.

14. To produce a barrel of oil from oil-sands mining requires 2 to 4.5 barrels of water (Griffiths et al., 2006). Moreover, over half of all oil produced in Alberta is from in situ projects using "enhanced oil recovery" i.e. injecting water to recover oil from the reservoir. The oil and gas industry's use of saline water has increased fivefold since 1999. Water demand for in situ oil sands projects is expected to more than double between 2004 and 2015 (NEB, 2006).

15. Water allocation licenses are now issued for a two-year period, with subsequent licenses eventually issued for a five-year term (Alberta Environment, 2006). This is a reduction from the previous 10-year renewal period, and renewal terms can now be changed by regulation. Moreover, licence transfers are now subject to a review process similar to new licence applications. 
water by allocating it to its highest value use. Furthermore, establishing a price for water would create an incentive for users to be as efficient as possible, thereby decreasing overall demand for water resources.

\section{The management of non-renewable resources should be improved}

The dependence of the economy, Alberta's in particular, on oil revenues poses vulnerability and sustainability challenges. Indeed, economic stabilisation is more difficult because of the reliance on fossil fuel revenues that are uncertain (in terms of value and timing) and unstable (because of the volatility of oil prices). Moreover, the resource raises questions of long-term sustainability and inter-generational equity within Alberta, because the oil is non-renewable. At the national level, these developments are generating large regional disparities, especially because some provinces are affected by negative externalities through the currency appreciation and have questioned the appropriateness of current inter-provincial redistribution mechanisms (see OECD, 2008b).

Fiscal policy in Alberta should be more prudent. Higher spending may be warranted to cope with the infrastructure shortage and may be politically difficult to avoid in the context of zero public debt and a comfortable surplus. However, public spending can exacerbate inflationary pressures in the short run and does little to prepare the economy to cope with the future costs of an ageing population, when the resource will be depleted. Other nations have shown much more restraint and foresight in managing their resource revenues to mitigate boom and bust cycles by saving their non-renewable resource revenues (see Box 2).

At the moment, Alberta has no framework or long-term goals for the use or investment of resource revenues. In 1976 the province set up the Heritage Fund to provide prudent stewardship of the savings from non-renewable resources. The investment objective of the Fund is to optimise long-term financial returns subject to an acceptable level of risk. However, there are no allocation rules for the province's resource revenues, and payments to the funds are discretionary. ${ }^{16}$ In addition, interest earned on its assets (less inflation-proofing) is being transferred to general revenues. As a result, the pace of accumulation is very slow, and the current value of the fund is low compared to those set up by other oil-producing countries or states. ${ }^{17}$

\section{Box 2. Non-renewable resource funds}

In some countries that are heavily dependent on the export of oil and other non-renewable resources, governments have established non-renewable resource funds (NRFs). The general justification for such funds is that some share of government revenues derived from the exploitation of a non-renewable resource should be put aside for the future, when these revenues decline, because the price of the resource has fallen, or the resource has been depleted or both. By placing the bulk of fund assets in foreign currencies, currency appreciation can be kept to a minimum, preventing the emergence of "Dutch disease"-type phenomena. Savings funds can also serve a stabilisation purpose by helping to reduce the impact of volatile revenue on the government and the economy by specifying a smoothed rate of spending from the fund, while allowing temporary deviations in case of shocks. Such predictability is very important to ensure real exchange-rate stability. Estimations suggest that oil funds are associated with reduced volatility of broad money and prices, and lower inflation (Shabsigh and llahi, 2007).

16. For instance, the Fund received a CAD 1.25 billion deposit from the 2006-07 fiscal surplus, representing around $18 \%$ of the government net revenue.

17. Despite large surpluses, current policy requires that the government remove a large part of revenues from the Fund. In 2006-07, it earned investment income of CAD 1.65 billion, most of which was transferred to general revenues, leaving only CAD 283 million in the Fund for inflation proofing. As a result, the current value of the Fund was approximately CAD 16.6 billion in March 2007 (USD 15.5 billion), while Alaska's held USD 38 billion and Norway's almost USD 300 billion at end-2006. 


\section{ECO/WKP(2008)26}

NRFs can take various forms, ranging from separate institutions with discretion and autonomy to funds that amount to little more than a government bookkeeping account. Resources available to an NRF may be large, lending importance to the way its operations are integrated with the budget; the management of the assets; and to issues of governance, transparency and accountability.

\section{The Norwegian State Pension Fund}

Norway established its petroleum fund by legislation in 1990, though accumulation in the fund began only in 1996. The Fund has the two-fold purpose of smoothing out spending of oil revenues and at the same time acting as a long-term savings vehicle to let the Norwegian government accumulate financial assets and cope with expenditures associated with the ageing of the population. The Fund serves as a fiscal management tool to ensure transparency in the use of petroleum revenues. It is integrated with the budgetary process: net accumulations in the fund are budget surpluses. The Fund is not earmarked for any specific purpose (despite the political aim of pension provision). Domestic spending from the Fund is restricted to the assumed long-run real rate of return (4\%) on the fund's outstanding value, which in turn determines the size of the non-oil budget deficit.

Norges Bank is responsible for the management of the Fund, on behalf of the Ministry of Finance. The fund is invested in financial instruments abroad, where $60 \%$ of the portfolio is allocated to fixed income instruments and $40 \%$ to equities. The Fund is also geographically well diversified. Indeed, the Ministry of Finance has defined a benchmark portfolio, which is a theoretical portfolio consisting of indices for the countries in which investments are allowed, and has set limits as to how much the Fund's investments may deviate from the benchmark.

\section{The Alaska Permanent Fund (APF)}

The APF was set up in 1976. Voters approved a constitutional amendment, which stated that "at least $25 \%$ of all mineral lease rentals, royalties, royalty sale proceeds, federal mineral revenue-sharing payments, and bonuses received by the State shall be placed in a permanent fund, the principal of which shall be used only for those income-producing investments specifically designated by law as eligible for permanent fund investments." The APF was thus established as a state institution with the task of responsibly administering and conserving oil and other resource royalties.

There are two parts to the Fund: principal and income. The principal is invested permanently in the capital markets, diversified among various asset classes and cannot be spent without a vote of the people. The Alaska Permanent Fund Corporation has been designated by law to manage the assets of both the APF and other state investments, separating the management and accounting of the Fund from the rest of state government. The Board's goal is to earn slightly better-than-average rates of return with slightly below-average levels of risk. The Fund has earned a $10.4 \%$ annualised total rate of return over the long run. This is in excess of its targeted rates of return during this time frame. Fund income can be spent, and decisions as to its use are made each year by the legislature and the Governor. The APF was established as an inviolate trust, meaning that the principal of the Fund is to be invested in perpetuity. It thereby transforms non-renewable oil wealth into a renewable source of wealth for future generations.

\section{Chile's Copper Stabilization Fund (CSF)}

In 1985, Chile established the CSF (now the Economic and Social Stabilization Fund) as part of a Structural Adjustment Loan agreement with the World Bank. The first deposit into the CSF was subsequently made in 1987. The rules of the CSF stipulate that deposits (or withdrawals) will be proportional to the excess of the copper price over trigger prices that are established as two bands (narrow and wide) around a reference price. The reference price is set in real terms (adjusted for dollar inflation) and cannot exceed a six-year moving average of the spot price. Within the narrow band there would be no deposit or withdrawal; outside the wide band all additional copper revenues are deposited (if the price is higher) or withdrawn (if the price is lower); and in between the two bands $50 \%$ of the excess are deposited or withdrawn. Furthermore, withdrawals are to be used only for "extraordinary amortizations of public debt".

Source: Website of the Norwegian Ministry of Finance http://www.regieringen.no/en/dep/fin/Selected-topics/The-GovernmentPension-Fund.html?id=1441, Hartzog (2002), Davis et al. (2001).

The provincial government has taken steps to address these issues. In its 2007 Budget, it announced a surplus management plan that included putting one-third of any unbudgeted surplus into the Heritage Fund 
and the balance into another savings fund, the Capital Fund. However, this savings plan applies only to one-third of any unbudgeted surplus and does not actually apply to any of the budgeted revenues. It will be important to make a more systematic use of these funds and in particular set up allocation and withdrawal rules. More specifically, setting up rules could anchor expectations, counteract real exchange rate volatility and appreciation. It could also enhance transparency (Davis et al., 2001). Such rules could also have some stabilisation objective, for instance when withdrawals are allowed to finance budgetary spending during recessions. In this context, the government of Alberta should use the opportunity provided by the announced review of the various provincial savings plans to reintroduce explicit withdrawal and accumulation rules. For instance, rules similar to those existing in Norway could be envisaged. ${ }^{18}$

The federal government also collects part of the resource revenue through corporate tax. For the time being, all unexpected surpluses are directed to pay down the federal debt, and the resulting interest savings are used to cut personal income taxes (the Tax Back Guarantee). In order to finance future ageing and health costs, and in the context of low net debt, it would be worth considering setting up a federal savings fund to which windfall gains from the resource sectors would be allocated. One possibility would be to assess the impact of oil prices on federal tax revenues and, making an assumption of a benchmark "equilibrium" oil price, to estimate the windfall gains from higher oil prices. Of course, this would represent only a rough approximation of the true resource revenues, as spillover effects to other sectors would not be taken into account, but a simple and transparent allocation rule would have the advantage of increasing the predictability of fiscal policy (Gianella, 2006).

\section{Curbing GHG emissions is a major concern over the long term}

GHG emissions and ensuing climate change are certainly the most pressing environmental problem confronting the energy sector in Canada. Emissions in 2005 were $33 \%$ higher than the Kyoto Protocol target, which is $6 \%$ below the 1990 baseline level. Looking forward, a recent official baseline scenario showed GHG emissions soaring in the future, with half of the projected rise attributed to the oil sands (Table 3). Indeed, the baseline implies that the Government of Canada's target of a $20 \%$ absolute reduction in greenhouse gas emissions from 2006 levels by 2020 requires a 330 megatonnes reduction from the reference case projected emissions level of 940 megatonnes in 2020. While all oil and gas producers are working towards decreasing their energy use and developing pollution-abatement technologies, the level of effort required to meet this target will make itincreasingly important to find and develop ways to reduce emissions on an economy-wide basis.

\section{Improving the design of current policies dealing with climate change and air pollution}

Current policies suffer from a number of shortcomings in their design and implementation. Indeed, jurisdiction over the many areas critical to climate-change policy is shared among federal and provincial governments: natural resources are under provincial responsibility, while international treaties and issues of general security are under federal jurisdiction. Consequently, the roles of the federal and the provincial authorities are not clearly defined and have resulted in the publication of environment plans by some provinces in addition to the federal plan (Box 3). The federal government has been working closely with provincial and territorial governments to minimise duplication and overlap. This will include the development of equivalency agreements with interested provinces that apply at least as stringent targets as the federal government. They aim to avoid as much as possible any duplication and to ensure consistency in the way regulations are applied. At this stage, however, it is unclear what the final outcome of this process will be and at what horizon full harmonisation will be achieved. Moreover, equivalency

18. Another possibility would be to re-establish the rule that prevailed before 1983 according to which $30 \%$ of resource revenues are set aside for the Fund. More stringent rules have sometimes been proposed. (Kneebone, 2006). 
agreements are of a bilateral nature, so that Canada could very well end up with ten different environmental plans and emissions trading schemes and associated intensity targets to curb GHG emissions. This could raise costs for firms, which would need to adapt to different provincial conditions. Overall, the current situation has increased uncertainty, thereby holding back the investment needed to ensure a sustainable development of the sector.

Table 3. Current and projected GHG emissions from energy

\begin{tabular}{l|rc|cc}
\hline \multirow{2}{*}{ Sector } & \multicolumn{4}{|c}{ Projected emissions } \\
\cline { 2 - 5 } & 2006 & 2020 & 2020 relative to 2006 \\
\cline { 2 - 5 } & Megatonne & Megatonne & $\%$ \\
\hline \multirow{2}{*}{ Residential and commercial } & 86 & 109 & 23 & 27 \\
Mining and manufacturing-regulated & 77 & 90 & 13 & 17 \\
Mining and manufacturing-non & & & & 39 \\
regulated & 28 & 38 & 11 & -14 \\
Conventional oil and gas production & 132 & 114 & -18 & 271 \\
and distribution and refining & 29 & 108 & 79 & -1 \\
Oil sands & 123 & 122 & -2 & 31 \\
Electricity and heat generation & 177 & 232 & 55 & 20 \\
Transportation & 104 & 124 & 20 & 24 \\
Others & 756 & 937 & 181 & \\
Total & & & & \\
\hline
\end{tabular}

Source: Government of Canada (2008), Turning the Corner: Taking Action to Fight Climate Change, March, Ottawa, www.ec.gc.ca/doc/virage-corner/2008-03.

The federal plan complemented many measures that have been implemented since the 2006 Budget but represents a major shift from a voluntary to a regulatory framework. Past environmental policies have been found to have had limited effects and to have suffered from shortcomings in their designs (Office of the Auditor General, 2006). This is consistent with findings from the literature. Indeed, measures of a voluntary nature (e.g. information programmes and subsidies) are found to be mostly ineffective when applied on their own, while policies that tax GHG emissions (a carbon tax) or regulate emissions (emission caps and permit trading) are found to be much more effective (Jaccard et al., 2006; OECD, 2003).

\section{Box 3. Federal and provincial plans for fighting climate change and air pollution}

On 26 April 2007, the federal government unveiled the Clean Air Regulatory Agenda, designed to address climate change and air pollution Additional details related to implementation of the Regulatory Framework for Industrial GHG emissions within the Agenda were released in March 2008. A number of provinces have also published environment plans in recent years.

\section{A description of the federal plan}

\section{Greenhouse gases}

The federal government is committed to reducing Canada's total GHG emissions, relative to 2006 levels, by $20 \%$ by 2020 and by 60 to $70 \%$ by 2050. The plan sets mandatory reduction targets for major industries that produce GHGs. In the short term, these targets are less ambitious than those set in the Kyoto protocol. Existing facilities should reduce their emissions per unit of production by $18 \%$ reduction from 2006 emissions intensity by 2010 . There should be a $2 \%$ annual improvement thereafter. The target will be applied at the facility, sector or corporate level, depending on the sector. Minimum thresholds will be set in five sectors to avoid imposing unreasonable administrative costs on small 
facilities. Fixed process emissions will be exempt from these targets. There is a three-year commissioning period for new facilities. After the third year, the initial GHG emission-intensity target will be based on sector-specific cleaner fuel standards, and subsequent annual targets require a reduction in emission intensity by $2 \%$ per year thereafter. All new oil-sands upgraders, in situ plants and coal-fired electric plants that come into operation during 2012 or later will be required to meet a more stringent target based on the use of carbon capture and storage by 2018 . The federal government will establish an electricity task force to work with provinces and industry to meet an additional 25 megatonne reduction goal from the electricity sector by 2020 . There will be an incentive for facilities to be built carbon-capture ready and to use high-efficiency co-generation in the form of lower required emission reductions in the short term.

Companies will be able to choose the best way to meet their reduction targets in a cost-effective way. This includes making reductions in their own facilities, investing in emissions-reducing technologies through a technology fund or taking advantage of domestic emissions trading (including offsets) to deliver reductions in Canada. They will also have access to international GHG credits provided by the Kyoto Protocol's Clean Development Mechanism to a maximum of $10 \%$ of each firm's regulatory obligation. The federal government will allow a one-time credit for early action to reward those companies that significantly reduced emissions during the 1992-2006 period. These credits will be tradable and bankable.

\section{Air pollution}

The plan also sets national limits for industrial emissions for four air pollutants that cause acid rain and smog (nitrogen oxides, sulphur oxides, volatile organic compounds and particulate matter). There will be also sector-specific caps. Companies will be able to choose the most cost-effective way to meet their targets. This includes making changes to improve their processes within their plants or buying new equipment or technology that will reduce smog and air pollution. Companies will also be able to take part in a Canada-wide trading system to buy credits if they have not reached their nitrogen oxides and sulphur oxides reduction targets. As a result, air pollutant emissions that cause smog and acid rain are expected to be reduced by up to $55 \%$ as early as 2012 .

\section{Other measures}

In addition, the government is committed to addressing emissions from transportation by regulating the fuel efficiency of cars and light trucks, beginning with the 2011 model year. Rules or regulations will be based on a stringent, dominant North American standard. The government has also announced that it will strengthen energy-efficiency standards for a number of energy-using products and take action to improve indoor air quality. It has also unveiled many other programmes and initiatives worth over CAD 10 billion since October 2006; these aim to measurably reduce the impact of GHGs and air pollution on the health of Canadians and the environment. Measures include the ecoENERGY Initiatives, the ecoTransport Strategy, the Trust Fund for Clean Air and Climate Change, support for public transit and support for the production of renewable fuels. In addition, the 2008 federal Budget includes new measures to promote carbon capture and storage and support nuclear energy and invest in research and development projects in the automotive sector for greener and more fuel-efficient vehicles.

\section{Provincial GHG targets}

Most provinces have some form of restriction on emissions of GHGs and/or air pollutants. However, standards vary considerably across the country. Alberta's Energy Strategy to 2025 is integrated in the provincial government's broader strategic document published in 2005. In March 2007, Alberta became the first province in Canada to enact specific GHG reduction legislation. Companies will have the choice of cutting their own emissions or of contributing to either a technology fund or an Alberta-based offset project. In January 2008, however, the province adopted less stringent emissions reduction target than previously envisaged. In June 2007, Ontario unveiled GHG targets and a plan to reduce its GHG emissions. It is counting on the planned shutdown of its coal-fired power plants and the use of more renewable energy to take it half way to its targets and will receive funds from the federal government to achieve this goal. British Columbia developed a comprehensive energy plan in 2002 that integrated energy policy and environmental imperatives toward 2015. In a new Energy Plan in April 2007, British Columbia introduced targets for zero net GHG emissions for all new energy production in the province. In 2006, Quebec released its energy plan, including energy and environment objectives to 2015. In 2007, the province of Newfoundland and Labrador presented an energy plan which aims to develop energy resources and ensure energy security and environmental sustainability. New Brunswick and Nova Scotia have announced targets, but these do not apply to major industries.

In August 2007, all Premiers agreed to implement energy conservation strategies and to reduce GHG emissions within their own jurisdictions, according to each province's climate-change plan (see Table 4).

Source: Government of Canada (2007a), Government of Canada (2008), provincial Ministries for the Environment, Council of the Federation (2007). 
ECO/WKP(2008)26

\begin{tabular}{|c|c|}
\hline & Table 4. Provincial GHG emissions targets \\
\hline Provinces & Targets \\
\hline Alberta & $\begin{array}{l}50 \% \text { GHG emissions intensity reduction relative to projected levels by } 2050 \text {, } \\
\text { equivalent to a } 14 \% \text { absolute reduction in emissions relative to } 2005 \text {. }\end{array}$ \\
\hline British Columbia & $\begin{array}{l}\text { At least } 33 \% \text { below } 2007 \text { levels by } 2020 \text { ( } 10 \% \text { below } 1990 \text { levels). Interim targets to } \\
\text { be set for } 2012 \text { and } 2016 \text {; long-term target to be set for } 2050 \text {. }\end{array}$ \\
\hline Manitoba & $\begin{array}{l}6 \% \text { below } 1990 \text { levels by } 2012 \text {. First step is to reduce emissions to below } 2000 \text { levels } \\
\text { by } 2010\end{array}$ \\
\hline New Brunswick & $10 \%$ below 1990 levels by 2020 \\
\hline $\begin{array}{l}\text { Newfoundland and } \\
\text { Labrador }\end{array}$ & $10 \%$ below 1990 levels by 2020 \\
\hline Nova Scotia & $10 \%$ below 1990 levels by 2020 \\
\hline Ontario & 6\% below 1990 levels by 2014; 15\% below 1990 levels by 2020 \\
\hline Prince Edward Island & 1990 levels by $2010 ; 10 \%$ below 1990 levels by 2020 \\
\hline Quebec & 6\% below 1990 levels by 2012 \\
\hline Saskatchewan & $32 \%$ below 2004 levels by 2020 \\
\hline
\end{tabular}

There has been a great deal of discussion on the choice of intensity (i.e. with intensity a measure of GHG emissions per unit of output) rather than absolute targets for GHG emissions. In particular, this implies a different treatment than for air pollutants, which will be subject to absolute targets. Both types of targets have advantages and drawbacks. Absolute targets offer the benefit of more direct linkage to the final environmental objective, but they are inflexible in the face of potentially high costs of action (Philibert et al., 2003). Intensity targets, conversely, are more sensitive to cost factors but have weaker linkages to any final objectives expressed in terms of atmospheric concentrations or warming (Blanchard and Perkaus, 2004). However, if intensity targets are set at a particularly stringent level they can lead to absolute reductions (World Resources Institute, 2006). Overall, the federal government's recent policies are an improvement on previous policies in that the intensity reductions on industrial emissions are likely to be greater than previous policies (Jaccard and Rivers, 2007) even though they will fail to meet the Kyoto targets (Table 5). However, this depends crucially on the use of the flexibility provisions, in particular emissions trading.

Despite the welcome move away from a voluntary approach, a number of limitations of the federal plan can be put forward, and some of these criticisms are valid for provincial plans as well. First, the regulation on industrial emissions at the federal level allows emitters to forego emissions reductions and, through emissions trading, instead pay firms and households in the unregulated sectors of the economy to achieve those reductions in their place. 
ECO/WKP(2008)26

Table 5. Federal GHG emissions targets

\begin{tabular}{cccl} 
& Relative to 2006 & Relative to 1990 & Relative to Kyoto target \\
\cline { 2 - 4 } 2020 & $20 \%$ below & approx. 2\% above & approx 8\% above \\
2050 & $60-70 \%$ below & approx. 49-62\% below & - \\
\hline
\end{tabular}

Source: M. Bramley (2007), "Analysis of the Government of Canada's April 2007 Greenhouse Gas Policy Announcement", Pembina Institute, 28 May, Calgary.

Second, the focus of the plan is on emissions-intensive industry, which represents only about $40 \%$ of total emissions. The transport sector is not subject to the GHG emission limitations, although it is expected to remain a large emitter in the two decades to come. There is currently a Memorandum of Understanding between the auto industry and the federal government, with a target of 5.3 megatonnes of GHG emissions reductions in 2010. Once this agreement expires, the government has committed to establishing a regulated fuel-efficiency standard for the 2011 model year, benchmarked against a stringent, dominant North American standard. The level of this standard will be determined through the normal regulatory process, including consultations with the automotive industry and other stakeholders. The use of standards may be justified in the presence of market failures which cannot be addressed by market instruments. But it remains to be seen whether these measures will be sufficient to curb GHG emissions markedly at the national level. In that context, there may be merit in Canada considering the introduction of a carbon tax as a complement to the use of standards in the transportation sector (see OECD, 2008b; Fullerton and West, 2000).

Finally, concerns have been raised as to the high cost of the proposed federal regulations. Preliminary analysis performed by Environment Canada indicates that the annual economic cost of meeting both the regulated GHG and the regulated air pollution targets are not expected to exceed $0.5 \%$ of GDP in any given year up to 2020, while the benefits associated with improved human and environmental health would be on the order of CAD 6.4 billion annually (0.5\% of GDP) (Government of Canada, 2008). Analysis by the National Round Table on the Economy and the Environment (NRTEE) points to an economic impact whose amplitude depends on the speed of emission reductions. Overall, these simulations indicate relatively small reductions in the size of the economy, with a maximum cumulative lost output from 2011 to 2050 of $2.9 \%$ of a business-as-usual forecast level (NRTEE, 2008). Prudence should nonetheless be exercised as these types of estimates are usually surrounded by significant uncertainties. They require an estimate of not only the direct impact on production costs but also of the indirect impact of those costs on future investment decisions, demand and supply, and related consequences for other businesses and consumers. There are many points of uncertainty throughout this chain of actions and reactions.

In addition to addressing the current limitations of environment plans, there is also a need to improve the delivery of efficiency measures aiming at lowering the demand for energy which can be useful when price instruments appear insufficient to foster energy-efficiency gains. ${ }^{19}$ Indeed, there is evidence that Canadian households engage in many practices that have a negative impact on the environment (Statistics Canada, 2007). To advance energy efficiency, a range of available policy instruments could be employed, including regulations and standards, fiscal incentives, public information campaigns, labels, and public-sector leadership in procurement. Regulations and standards are generally perceived as less costly, but their final costs can be high. Although they are generally not efficient, they can address market failure in some specific cases. Information instruments are efficient in the case of asymmetric (or lack of) information and may or may not be expensive.

19. This includes, for instance, retrofitting buildings or tightening requirements on new buildings. 
At the moment, a number of specific product standards exist, and further efforts are planned. ${ }^{20}$ However, the efficiency of these measures remains generally limited because some of them rely on voluntary action, or the general public may not be aware of their existence. Consolidating and streamlining the overall package of measures would help. It would be preferable to concentrate efforts on those that are most cost-effective.

\section{Making more use of market-based instruments}

More generally, even if it recognised that Canada's proposed greenhouse gas regulations are expected to include provisions for emission trading, the efficiency of current policies could be enhanced by focusing more on market-based instruments (such as tradable permits and tax measures, which put a price on carbon) and less on traditional, command-and-control regulation. Indeed, market-based instruments are an effective and economically efficient means for reducing emissions as they send a clear signal on prices. Market-based instruments increase the relative cost of emissions-intensive technologies and products, creating a continuous incentive for innovation to improve efficiency or to shift to lower-emissions substitutes. When applied in a predictable and persistent fashion, these approaches can also encourage the deployment of low-carbon technologies and promote technology transfer to less developed countries. Recent estimations suggest that a phased-in carbon price in Canada of CAD 75 per ton by 2020 could lead to $21 \%$ emission cuts relative to business as usual and could generate some CAD 53 billion in revenues (2.9\% of GDP) in 2020 (Rivers et al., 2008).

Despite these advantages, market-based instruments have not been widely implemented in OECD economies, and in Canada in particular, because of their potential distributional leakages and competitiveness effects. Depending on their design, these tools can have disproportionate effects on low-income households. However, personal income tax cuts or increases in benefits can mitigate these distributional effects (OECD, 2006a). ${ }^{21}$ The imposition of an additional cost on firms and the resulting impact on international competitiveness has been a major concern, particularly in commodity-based sectors where the market price is set internationally and where firms are not able to pass on this extra cost. Recycling a portion of the tax revenues back to the affected firms could lower the effectiveness of the policy (OECD, 2006a). By contrast, increasing international coordination of policies could mitigate these competitiveness impacts and would be a first-best solution. Competitiveness concerns could also be addressed by a shift in the tax mix so that the overall cost would not be overly augmented. One possibility could be to increase environmental taxes, whose level is currently low by OECD standards (Figure 6) and lower other corporate taxes. This could also have the advantage of improving the efficiency of the tax system (see OECD, 2008b).

\section{Emissions trading}

Well-designed emissions trading has great potential for reducing emissions of GHG and other pollutants from energy production, use and sources when energy markets are competitive. ${ }^{22} \mathrm{~A}$ cap-and-trade system requires emitters to hold permits that provide the right to emit a certain amount of

20. Under the Energy Efficiency Act, the government plans to impose: new energy performance standards for 18 currently unregulated products, such as commercial clothes washers and commercial boilers; and more stringent requirements for 10 currently regulated products, such as dishwashers and dehumidifiers.

21. These tools are preferable to tax rate reductions or exemptions because they maintain the price-signal mechanism of the instrument.

22. There is a range of possible models for emissions trading, including cap and trade, baseline and credit, and hybrid schemes with cost capping and other variations. Each may have implications for the design of the broader international framework. For example, cap and trade or baseline and credit schemes would require agreed targets, while other models may require international agreement on prices or other parameters. 
GHGs and allows them to buy and sell permits in an open market. The sum of the permits corresponds to the overall desired level of emissions of the covered sources. The economic superiority of a system of tradable permits compared to a pure command-and-control regulation rests on its ability to equalise marginal costs among all controlled sources, thereby assuring least-cost compliance with the particular environmental goal. Or, for a given cost, more environmental benefit can be gained (Ellerman, 2000).

Figure 6. Revenues from environmental taxes ${ }^{1}$ Per cent of GDP

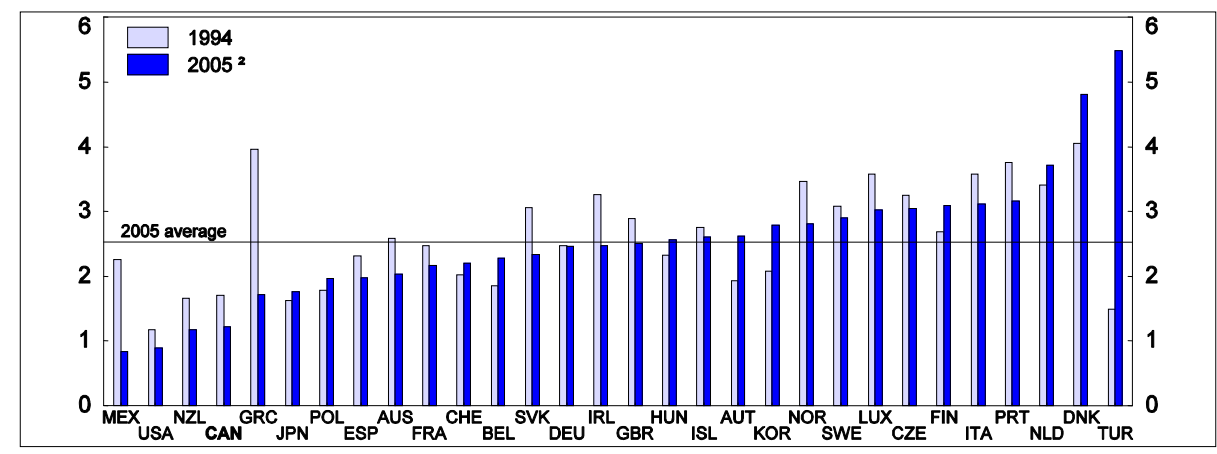

1. Data refer to revenues from environmental taxes for pollution control.

2. 2004 for Iceland.

Source: OECD (2006), Consumption Tax Trends, 2006 Edition, OECD Publishing, Paris.

Emissions trading allows for the development of financial instruments to manage risk. However, this requires setting scientifically credible and economically achievable emissions-reduction targets, while giving companies maximum flexibility to achieve those goals. This could entail adopting better control technologies or purchasing "reductions" from a source whose cost of cutting emissions is lower. In this context, having access to an international emissions-trading system will be particularly important.

The banking of allowances, whereby permits that are not used in the trading period for which they are issued may be banked for use in a later trading period, is also an important feature of efficient trading systems. This allows firms to adjust their emissions reduction schedules to their investment programmes. By letting firms smooth their emissions profiles through the business cycle, it is also a way to manage price volatility (Philibert and Reinaud, 2004). Recent estimations suggest banking reduces abatement costs, while it also increases the amount of GHG emissions abated in the short term (Bosetti et al., 2008).

A number of provincial and federal initiatives are currently underway to set up carbon trading systems. The federal plan indicates the government's willingness to implement an emissions-trading market for GHGs that will be part of the Regulatory Framework. It will have a number of components. A domestic inter-firm trading system, through which regulated firms may buy and sell emissions credits among themselves, will be the central feature. A domestic offset system will allow regulated firms to invest in verified emissions reductions outside the regulated system. In addition, Canadian firms will have access to most qualifying credits from the Kyoto Protocol's Clean Development Mechanism, with the exception of credits from forest sink projects, for compliance with the regulations. Plans to set up a market have also been announced in a number of provinces, in particular in Alberta and British Columbia. ${ }^{23}$ However, a number of implementation issues need to be resolved:

23. In June 2007, the Eastern Canadian premiers and New England governors also said they will look more closely at developing a regional system for capping and trading greenhouse gas emissions. 
- First, decisions have to be taken regarding the allocation of permits. This could be done using an auction or through free distribution to emitters according to some principle, usually historical use (grandfathering). Grandfathering is the more politically feasible alternative and is often used to gain the consent of incumbents for the measures being proposed, but it gives a premium to those who polluted the most in the past. By contrast, auctions increase incentives to reduce emissions, but they impose an additional burden on firms. Coupling auctions with recycling revenues back to the firms could be an option as long as they do not lower the effectiveness of environmental measures. In any case, decisions on how permits are going to be allocated need to be taken rapidly in order to reduce uncertainty. Emissions-trading also requires clarity on the assumptions for economic growth and baseline carbon-intensity improvements, orderly and transparent release of periodic market-relevant emissions data and the imposition of strict penalties for fraud or non-compliance.

- Second, restricting the scope of trading to the Canadian market may generate a high cost of compliance and lead to insufficient liquidity. In this context, the federal government has indicated it will work toward potential linkages with trading systems in the United States, Europe and Mexico. The province of British Columbia is also seeking to participate in the EU carbon-trading market. These initiatives are laudable steps but will not be straightforward. Indeed, the harmonisation of current schemes, which can have different geographical/sectoral scopes, design characteristics, compliance provisions and rules for "offset" credits, is likely to be long and arduous. Monitoring exchanges in international markets also presents technical difficulties, and standardised reporting protocols for emissions data and penalty procedures need to be put in place to limit fraud. ${ }^{24}$ It will also be important to ensure that equivalency agreements do not prevent or render extremely difficult the linking of Canadian trading systems to other international schemes.

\section{Carbon tax}

Introducing a carbon tax (either at the federal or provincial level) can also force agents to internalise the cost of GHG emissions by raising the price of the associated fuels, processes and products. These fiscal incentives can reduce the demand for harmful products and increase it for alternative fuels, such as renewable, whose prices thereby become more competitive. They also increase incentives for the private sector to undertake R\&D on sustainable innovations and technologies. At the moment such a tax, however modest, exists in Quebec. ${ }^{25}$ A more substantial carbon tax has also been introduced in British Columbia and will take effect in July 2008. It is a tax on the purchase or use of fuels, such as gasoline, diesel, natural gas, heating fuel, propane and coal, and on tires when used to produce energy or heat. It is intended to be revenue neutral, and revenues from the tax will be returned to taxpayers through reductions in other provincial taxes. The carbon tax starts at a rate based on CAD 10 per tonne of associated carbon emissions and will rise by CAD 5 a year for the next four years. This corresponds to 2.4 cents per litre for gasoline, rising gradually to 7.24 cents a litre by 2012. For diesel and home heating oil, it works out to 2.76 cents per litre, rising to 8.27 cents over the same five-year period.

24. The credibility of the penalty structure is relatively easy to achieve for sovereign authorities implementing a tradable permit system within a nation. However, a credible penalty structure is hard to imagine at the international level. In particular, the issue of "over-selling", whereby a party sells too many permits and fails to cover its own emissions needs, will have to be addressed.

25. Quebec implemented Canada's first carbon tax in October 2007. The tax amounts to 0.8 cents on every litre of petrol sold in Quebec and 0.9 cents on each litre of diesel fuel. About 50 companies are affected by the tax. About CAD 200 million in annual revenue is expected to be raised, thereby paying for energy-saving initiatives such as improvements to public transit. 
The economic effect of a (provincial or national) tax depends on its rate and coverage, as well as the monetary-policy and exchange-rate response to its economic impacts, and is empirically difficult to estimate. ${ }^{26}$ The main difficulty in introducing a carbon tax in Canada is political, as it implies increasing firms' tax burdens and would run counter to the downward trend in corporate taxation in Canada and more generally in OECD countries. In addition, it could be argued that the setting up of technology funds within current environmental plans already taxes firms. Firms can indeed meet part of their regulatory obligations to reduce GHG emissions by contributing to a fund that will be used to finance investments in energy-saving technology. However, technology funds and a carbon tax are not comparable: the use of the fund is voluntary, and resources will be used to develop technology, while a carbon tax would be compulsory and resources would not be earmarked for any specific use. Moreover, as suggested above, changing the tax mix and cutting corporate tax rates could leave the overall business tax burden for firms unchanged.

One other important criticism of the imposition of a carbon tax is that it is an inflexible tool and cannot be easily adjusted for changing emission levels. In the limit, governments could become reliant on the revenues and be less willing to adjust the tax rates downward when emissions decline as would be called for if the marginal external cost of emissions is increasing. By contrast, tradable permit regimes can be more effective and more flexible, but they involve greater cost uncertainty and may thus curb investment to a greater extent. In theory, emissions trading should result in exactly the same cost as a GHG tax for a given level of emissions reductions. In practice, emissions-trading guarantees a certain level of emissions, while costs are uncertain. In contrast, a GHG tax guarantees a certain maximum cost, while the extent of emissions reduction is uncertain.

There may be some potential advantages of setting up a hybrid system whereby the permit price can fluctuate within a pre-defined corridor with taxes ensuring the floor and subsidies the ceiling. This would reduce compliance-cost uncertainty of tradable permits, and, in the short term, the system would be similar to a tax. A mixed system of both trading and taxation can lead to better welfare outcomes in the presence of non-linear environmental damage and uncertainty concerning abatement costs (Roberts and Spence, 1976). However, the combination can increase the uncertainty regarding environmental effectiveness compared to the sole use of emissions trading (OECD, 2006a). In this context both federal and provincial authorities should carry out a thorough assessment of the benefits and costs of having a hybrid system.

\section{Moving the energy mix toward low or zero-GHG emissions sources}

Given the amplitude of the climate-change challenge, it will be important to supplement market-based instruments and environmental policies with other policies that promote the use of low GHG-emissions sources. Stimulating the intensity of competition in energy markets and providing targeted fiscal incentives could boost sectoral innovation and steer outcomes toward lower GHG emissions paths.

26. Jaccard (2007) estimated that a CAD 50 per tonne carbon tax beginning in 2006 would shave about CAD 4.8 billion (about 0.3\%) from Canada's GDP in 2010. The impact would become insignificant for the economy by 2020. According to a 2007 federal government study of measures required to meet Canada's target under the Kyoto Protocol within the agreement's commitment period, a more drastic scenario of imposing a carbon tax at a per tonne rate of approximately CAD 195, which would apply to all GHG-producing activities by the industrial, commercial and household sectors, would reduce GDP by some 7\% compared to a business-as-usual scenario in 2008 and 2009 (Environment Canada, 2007b). This scenario certainly overestimates the impact of the carbon tax as it excludes any monetary-policy reaction. 


\section{Liberalise electricity markets}

Competitive electricity markets with cost-based prices are a strong instrument to effectively balance energy systems in terms of economic efficiency, reliability and environmental responsibility. Electricity regulation is more restrictive in Canada than in most other OECD countries (Figure 7). This reflects a range of disparate situations across provinces. In most cases, electricity markets are exposed to only limited competition, suppliers are vertically integrated, public ownership remains prevalent, and there is open access to the grid only for generators and wholesale purchasers. Only Alberta and Ontario have full retail markets. In Ontario new projects get the market price, while others get regulated prices set every six months for residential and small commercial users. Until $1^{\text {st }}$ April 2008 the latter was capped at around 25 times the power used by a typical residential customer. At that point it dropped to 15 . The non-profit sector was to be deregulated at the same time. Peak-load pricing will be adopted for all residences by 2010 .

There is a wide dispersion of electricity prices across provinces (reflecting both the availability of different types of generation and the regulatory structure), but also between user types within the same province (Hydro-Quebec, 2006). This suggests the existence of cross-subsidies from small to large power users (Boyer, 2007). By encouraging energy-intensive forms of production, these implicit subsidies are inconsistent with current conservation objectives. Moreover, they distort price signals and can reduce incentives to invest in the energy sector, both in hydro electricity and other energy sources, because of unfairly low electricity prices for large-scale users most likely to undertake investments in the first place.

Figure 7. Electricity regulation in 2003

The indicator ranges from 0 (least restrictive) to 6 (most restrictive)

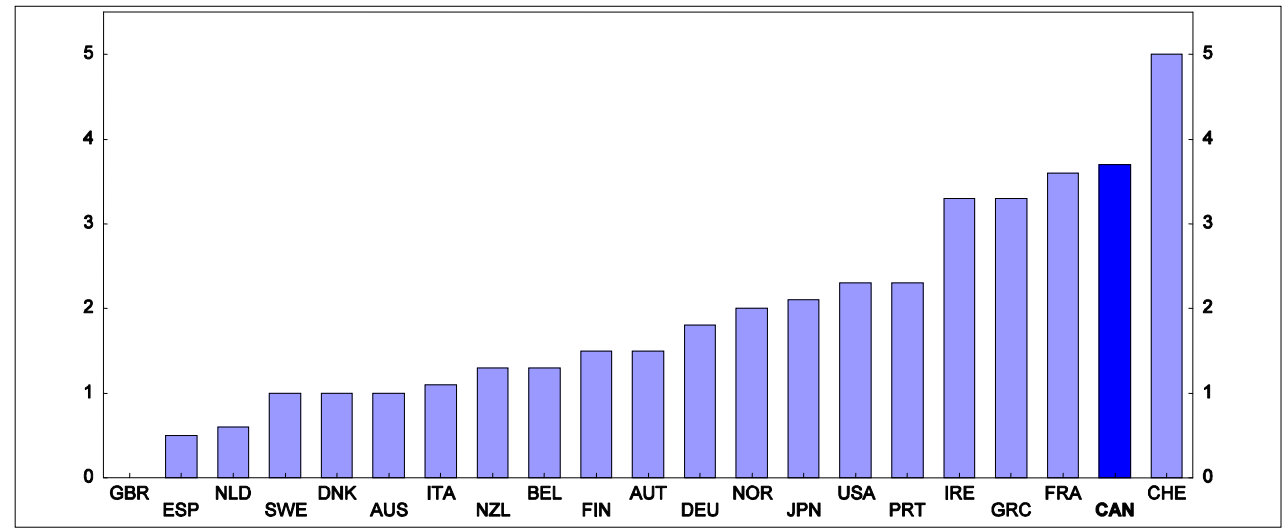

Source: OECD, Regulatory Indicators database.

Injecting more competition into provincial electricity markets would generate substantial benefits (see, for instance, Clark and Leach (2007) for Quebec). It would put pressure on companies to use resources more efficiently by ensuring prices match the true value of electricity (i.e. its opportunity cost). Moreover, experience in the United Kingdom, Australia and the Nordic countries shows that, with the right incentives and a stable investment climate, investors respond to market signals and add new capacity in good time (IEA, 2007b). In addition, investors also seem to take the need for energy diversification into account when incentives are clear. Higher electricity prices are likely to alter the economics of other renewable sources of energy (such as wind or biomass) and make them more profitable. Finally, removing cross-subsidies and imposing customer metering where it is not in place can offer substantial opportunities to improve energy efficiency.

There have been some claims that full and open competition and the subsequent rise in electricity tariffs, following the removal of subsidies, would affect mostly low-income households. It is not clear that 
this can be fully substantiated. Indeed, low prices currently produce a regressive transfer from the poor to the rich. In particular, maintaining prices below full costs deprives the government of resources to finance assistance programmes for the poorest citizens. In any case, concerns about the impact of higher electricity prices on low-income households could be addressed by refundable tax credits.

A number of provinces have detailed energy plans, but they are often incomplete, and implementation is slow. The government of Ontario has committed to replacing all the province's coal power plants by the end of 2014 to reduce emissions of air pollutants and GHGs. However, it remains unclear to what extent nuclear power will be used in replacement, as the four remaining coal plants account for some $20 \%$ of Ontario's current supply of energy (Urquhart, 2007). Moreover about 80\% of existing power facilities are ageing and will need to be refurbished over the next 20 years. Against this background, the province has been developing an Integrated Power System Plan, which outlines the projects necessary to maintain a clean, reliable and affordable supply of electricity in the province over the next 20 years. At this stage, it looks as though conservation will be relied upon to replace the coal-fired capacity; the nuclear plants will be modernised; and demand growth will be met by expanding the use of renewable and gas-fired generation.

Making better use of existing power assets via inter-provincial trade is one way to effectively delay the need for new generation capacity. Since 1995, the Agreement on Internal Trade (AIT) has aimed at reducing internal trade barriers for the main economic sectors. Nevertheless, a recent survey indicates that a majority of the 181 Canadian businesses surveyed experienced problems from internal barriers whose main impact was to raise costs (Conference Board of Canada, 2006). In particular, only little progress has been made so far in the energy chapter for which negotiations are still underway, though Ontario and Quebec have agreed to build a new interconnection of 1250 megawatts starting in 2009. By contrast the bilateral Trade, Investment and Labour Mobility Agreement (TILMA) signed in 2006 by the provinces of Alberta and British Columbia has dismantled non-tariff barriers to trade across major sectors including energy. The Council of the Federation, which is composed of the provincial Premiers, will investigate whether some elements of this agreement could be used in the AIT energy chapter. This initiative should be pursued, and inter-provincial trade in energy goods and services should be liberalised as soon as possible in order to facilitate a better allocation of resources across the country.

\section{Improve the support to renewable energy}

At the moment renewable energy sources receive sizeable financial support. Clean energy generation benefits from federal accelerated capital costs allowances, and renewable energy development is further encouraged through the eco-ENERGY Initiatives. Specific provincial policies also seek to hasten renewable energy supply. ${ }^{27}$ But both the design and the delivery of programmes could be improved. In many cases there are overlaps or duplications of measures that are provided both at the federal and provincial levels.

In addition, it is not clear whether the focus of current policies on certain energy sources such as corn ethanol or biodiesel is appropriate. ${ }^{28}$ Indeed, there is still a debate concerning the level of full-cycle energy

27. In 2004, the government of Ontario set a target to produce $5 \%$ of the province's electricity from renewable sources by 2007 and $10 \%$ by 2010 .

28. On 5 July 2007, the federal government announced the creation of the ecoENERGY for Biofuels Initiative, which will invest up to CAD 1.5 billion over nine years to boost Canada's production of biofuels such as ethanol and biodiesel. Ontario imposed 5\% ethanol content in motor vehicle fuel in January 2007. At the same time the province ended a preferential tax treatment previously granted to ethanol. The resulting proceeds (of CAD 520 million over ten years) will be recycled to a capital fund and support the production of ethanol in the province. See OECD (2008b) for further discussion. 
savings associated with ethanol fuels. When soil acidification, fertiliser use, biodiversity loss and toxicity of agricultural pesticides are taken into account, the overall harmful environmental impacts of corn ethanol and biodiesel can exceed those of petrol and mineral diesel (Doornbusch and Steenblik, 2007). Cellulosic ethanol may lead to more energy savings and GHG emissions reductions, but the competitiveness of Canada's cellulose-based ethanol remains uncertain (see OECD, 2008b) ${ }^{29}$ Given the latest available knowledge on the development costs of biofuels and their environmental impact, current support to corn ethanol and biodiesel needs to be re-considered.

Conflicting policies within a jurisdiction can also hinder the deployment of renewable energy. In Alberta, for instance, wind energy benefits from financial support, but the province also caps the production of such energy. Lastly, it is sometimes difficult to track how public funds are being used. Overall, there appears to be a need to investigate the efficiency of the current support provided to renewable energy and streamline its delivery. In particular, it is unclear whether significant aid will still be necessary once an effective emissions-trading system is put in place and increases incentives to use renewable energy.

\section{Foster innovation in the energy sector}

The challenges of long-term energy security and environmental sustainability can be met only through the deployment of efficient and cheaper technologies that are capable of using more plentiful, cleaner and cheaper sources of energy. In addition to the diffusion of current clean-energy technologies, better technologies need to be developed and implemented. Canada's innovation rate could be raised by a number of institutional changes, in particular by ensuring that firms operate in a competitive environment (OECD, 2006b). Additional changes are also needed to spur innovation in the energy sector, for instance to reduce air pollution, a field in which Canada's share of patent applications is low.

In its Science \& Technology Strategy, the federal government indicated its willingness to focus funding on priority areas that are in the national interest from a social and economic perspective (Government of Canada, 2007b). This includes environmental science and technologies, and natural resources and energy. This strategy is a promising attempt to integrate energy and environmental concerns into the national innovation system. But it remains to be seen whether it will lead to sufficient coordination of energy, environmental and research policies to promote innovation at the implementation stage.

\section{Box 4. Carbon capture and storage}

Carbon dioxide capture and storage (CCS) is a process that traps carbon dioxide $\left(\mathrm{CO}_{2}\right)$ at power plants and industrial facilities before it is emitted and then injects it into underground storage sites, reservoirs or possibly oceans. It is considered to have a fairly large technological potential to mitigate GHG emissions, although it will not by itself be sufficient to address the challenge of climate change.

Although the capture part of the CCS chain is used as part of industrial processes, storage is not used except in a few pilot projects. The extent to which this technology will be exploited will depend on the costs of CCS. In particular, the price of $\mathrm{CO}_{2}$ would have to be high enough to cover its incremental costs. CCS is more costly than biological sequestration. Analysts estimate the $\mathrm{CO}_{2}$ price would need to be in the range of USD 15 to 90 per metric tonne to cover the anticipated costs of CCS and exploit the full potential for geological storage. This wide range depends on the type of plant at which $\mathrm{CO}_{2}$ is captured and the distance of this plant from the storage facility. If all the sources that could eventually employ CCS did so, and assuming that their emissions would remain at 2005 levels, it would take between 500 and 1500 years to fully exploit the capacity of potential geological storage sites in the United States and Canada.

29. The government is committed to facilitating the commercialisation of cellulose ethanol, and the 2007 federal Budget allocated CAD 500 million for large facilities producing "next generation" renewables. 
There are a number of issues related to the implementation of CCS over the long term. Indeed, geological storage, although expected to be relatively secure, may not be permanent. There is also a need to assign financial responsibility for verification and monitoring of storage reservoirs, and for any damage from leakage. Implementing geological sequestration also raises issues of surface and sub-surface property rights and associated legislation.

Source: Congressional Budget Office (2007).

A number of measures have been adopted to encourage environmental innovation by supporting a wide range of technologies within these priority areas. ${ }^{30}$ Providing broad support appears appropriate in the current context, as there are no clearly superior approaches among the group of mature generation options, and several technologies will most likely be needed to deliver energy efficiently now and in the future. It will avoid introducing distortions in the market and favouring the development of any particular technology. At the same time, some targeting may be needed to limit fiscal costs. One alternative would be to support the development of technologies that are likely to bring the most value added. This could be those for which the country has a comparative advantage to develop this knowledge (either in the form of expertise in the field or supplies of a natural resource). It could also be technologies that have a large potential to lower emissions over their life cycle (and not only through their direct effect) and that could be easily exported to other countries. At the moment carbon capture and storage appears to meet these criteria (Box 4). The province of Saskatchewan has been a leader in the development of this technology, and has proposed to put in place a full-scale commercial demonstration of carbon capture and storage in the coal-fired electricity sector. The 2008 federal Budget provides CAD 240 million in trust in the fiscal year 2007 to Saskatchewan for this initiative, which will be matched by the province and used to partner with industry. However, it will be crucial to design public support effectively so as to limit crowding-out effects, whereby public investment is done at the expense of its private counterpart. Moreover, the efficiency of the support should be regularly examined.

A major role for the government is also to clear away hurdles from financing environmental innovation. A fund of CAD 550 million provided to Sustainable Development Technology Canada was established in 2002 to address the gap in funding at the demonstration and pre-commercialisation stages, just prior to venture capital investment. The Fund has been successful in providing support to 133 projects involving over a billion dollars of investment thus far, in particular in the energy production and exploration sector. However, its actions are limited to Canadian registered firms, and, as with most other R\&D measures in Canada, the support is mostly concentrated on small and medium-size firms, while there is evidence that foreign and large firms account for a large part of innovation (OECD, 2006b). Unless there is strong evidence that the latter can better internalise the benefit of innovation, it would be useful to direct part of the aid provided by the Fund to these firms.

30. The federal government is encouraging environmental innovation by: $i$ ) creating clear and effective policy frameworks for the environment, including the Regulatory Framework for Air Emissions to reduce air pollution and greenhouse gas emissions, the Clean Air and Climate Change Trust Fund (CAD 1.5 billion) to support major projects with the provinces and Territories to reduce GHGs emissions and air pollutants and the Comprehensive Chemicals Management Plan to manage known and potentially dangerous substances, such as mercury; ii) creating the EcoENERGY Technology Initiative (CAD 230 million) to reduce air pollutants and GHG emissions from conventional energy sources and increase Canada's supply of clean energy, including through the development of alternative, sustainable energy technologies; and iii) supporting collaborative research initiatives to improve the recovery of energy from traditional sources and develop alternative forms of energy. The 2007 Budget provided CAD 15 million to advance collaborative academic research in these areas and create the Canada EcoTrust for Clean Air and Climate Change to support relevant provincial and territorial projects. 


\section{Adapt taxation and regulation}

\section{Remove the preferential tax treatment of the oil and gas sector}

At the moment, the oil and gas sector benefits from favourable tax treatment, especially at the provincial level. Alberta collects rents through royalties, corporate taxes and lease sales. Its corporate tax rate is the lowest in Canada (10\% for the general rate and 3\% for small businesses). In exchange for a portion of the revenues, oil-sands companies lease the right from the provincial government to develop the resource and sell the product. This collection is done by sealed bidding in an open market to maximise value to the resource owner. In 2006-07, oil-sands leases generated CAD 1.3 billion to the Alberta government (Canadian Association of Petroleum Producers, 2007b). ${ }^{31}$

Royalties for conventional oil and gas fit into a complicated structure based on well size, age and production. For the oil sands a different regime was introduced in 1997, known as the generic oil-sands royalty rate, which is more generous than the system existing for conventional oil or natural gas. ${ }^{32}$ The system aimed to foster development at a time when uncertainties surrounding oil-sands exploration and development were much higher than today and when ecological concerns were not so prevalent. As a result, royalties have not kept pace with oil-price increases since the mid-1990s. Looking ahead, the continuing shift from conventional to non-conventional oil and gas would have led to a lower average effective royalty rate, assuming no change is made to the royalty regime. The Alberta Department of Energy estimates that oil-sands royalty revenues would have been the same in nominal terms in 2020 as in 2004-05, despite a tripling of production over that time period.

The current Alberta royalty regime is generous compared to systems applied in other oil-producing countries. The Alberta regime in place until end-2008 leaves 53\% of net revenue available from oil-sands developments with companies, while governments retain only 47\% (Alberta Royalty Review Panel, 2007). By comparison, firms undertaking oil and gas developments in Norway receive only $22 \%$ of the revenues. Concerns have recently mounted that Albertans are not receiving a fair share of the resource rent, while being adversely affected by the negative environmental and socio-economic consequences of oil-sands developments.

Against this background, the Government of Alberta announced a new royalty framework to take effect in 2009 following a thorough review by an independent expert panel (Government of Alberta, 2007). The conventional oil and natural gas royalty regimes will be simplified and made more sensitive to oil prices and production volumes. Moreover, royalty rates for oil-sands production will be increased. In addition, the provincial portion of the Accelerated Capital Cost Allowance for oil-sands projects will be eliminated. The resulting rise in royalties is expected to be CAD 1.4 billion dollars in 2010, a 20\% increase over royalty revenue projections under the current system. Conventional oil, natural gas and oil sands will each experience an increase in royalty payments of about CAD 460-470 million. Overall, these changes will increase Albertans' share of the resource and strengthen the need to improve its long-term management and the use of savings funds by the provincial government. Given the rapid development in the oil-sands industry and potential technology breakthroughs, it will be necessary to regularly review the royalty regime and see if it continues to serve the province's needs. One possibility could be to have a formula whereby parameters are reset in line with key competitor country royalty rate changes.

31. This corresponds to an effective tax rate of about $8 \%$ on the value of oil-sands output.

32. The current oil-sands regime includes an accelerated capital write-off period in which the royalty is $1 \%$ of gross revenues. Once the capital has been paid off, the royalty switches to a rate of $25 \%$ of net revenues or $1 \%$ of gross whichever is greater. For comparators, natural gas royalties range from 30 to $50 \%$ of gross revenues, while for conventional crude oil rates are as high as $40 \%$. 
At the federal level, recent changes have moved toward the gradual removal of the advantages favouring the oil sector. In the 2003 federal budget the government introduced a number of measures to be phased in over a five-year period, including the reduction of the federal corporate rate on resource income from 28 to $21 \%$, the phase-in of the deduction for income tax purposes of provincial royalty and mining tax payments and the phase-out of the existing $25 \%$ resource allowance. These measures were intended to improve the neutrality of the resource tax system, yet the impact of royalty deductibility may have some undesirable features (see OECD, 2008b). In the 2007 federal budget, the accelerated depreciation allowance for the oil sands was eliminated, but it still exists for mining. Moreover, there remain some tax preferences within the sector. For instance, the mining sector is allowed $100 \%$ deductibility for the intangible costs of developing a new mine (including an oil-sands mine), whereas intangible development costs of oil and gas wells (including in situ methods of oil-sands extraction) are eligible for a $30 \%$ per year deduction only. This could distort choices in the extraction methods used by oil-sands producers. It would be preferable to level the playing field between technologies. Moreover, no change has been made to the tax provisions relating to exploration or development expenses or to "flow-through shares". ${ }^{33}$ These provisions were introduced at a time when exploration entailed very large costs and it was difficult for small firms to finance exploration and development. Given the marked rise in the oil price and the prominence of environmental concerns, it is unclear whether the federal government should continue to encourage exploration through these provisions. Their phasing-out should be considered. Make the tenure regime consistent with environmental concerns.

The vast majority of Alberta's oil and gas resources is owned by the Crown, and the province leases the right to extract and produce oil sands to private companies. Leases generally run for 15 years and can be continued indefinitely past their initial term. ${ }^{34}$ As with its royalty regime, Alberta's tenure allocation system has been designed to encourage investment and the development of the oil sands. But it has not been revised since the 1980s and is now inconsistent with the Government of Alberta's 1999 Commitment for Sustainable Resource and Environmental Management (Holroyd et al., 2007). To continue a lease, a company must either produce oil, or sufficiently evaluate the oil-sands deposits and report on the amount of oil-sands reserves. ${ }^{35}$ This mandatory exploration/production requirement has been judged to contribute significantly to ecosystem disturbance (AXYS Environmental Consulting Ltd. and Lorrnel Consultants, 2002). Moreover, the cumulative impact of both new and existing projects on the environment is not properly assessed. In sum, the oil-sands tenure process should be reviewed and made consistent with the province's sustainability objectives.

33. Flow-through shares are a financing mechanism that assists a mining or oil and gas corporation to raise capital for exploration and development expenses. In addition to an equity interest in the issuing corporation, flow-through shares transfer to the purchaser of the share the right to the income tax deductions associated with the firm's expenditures on exploration and development. Flow-through shares are particularly important as a financing mechanism for smaller oil and gas and mining corporations that are not currently in a taxable position and do not have easy access to alternative financing arrangements. The Canadian exploration expense (CEE) is deductible at a rate of $100 \%$. For the mining sector, CEE has a broader definition than for oil and gas, as it also includes pre-production development expenses. The Canadian development expense (CDE) is deductible at a rate of $30 \%$ on a declining balance basis. For the oil and gas sector, CDE covers mainly the costs of drilling, converting or completing a well in a known reservoir. For the mining sector, it includes mainly the cost of building mine haulage ways and other workings after a mine has come into commercial production. It also includes the cost of acquiring a mining property in Canada.

34. Permits that run for five years and can be converted to leases are another existing tenure instrument, but they are less common than 15 -year leases.

35. In addition, an escalating annual rent is charged for all continued oil-sands leases that do not meet a minimum level of production, although it can be offset by research, development or exploration costs. 


\section{Streamline and reduce uncertainty in the project-approval process}

The approval process of energy projects is fragmented, complicated and requires applicant firms to provide detailed information at multiple stages. Moreover, many institutions are involved in the process. This has resulted in a lack of coordination and accountability and has become a significant obstacle to the development of major resource projects. This holds for oil-sands developments but also for other kinds of energy across the country, including liquefied natural gas and nuclear. ${ }^{36}$

The 2007 federal budget took an important step in addressing the issue by putting in place a Major Projects Management Office, which provides a single window on the federal regulatory process for industry. It improves overall accountability by monitoring and reporting on the performance of federal regulatory agencies. The Office serves as the focal point for developing legislative and administrative options to further consolidate and streamline regulatory processes.CAD 150 million over five years was allocated to create the Major Project Management Office and enhance the scientific and technical capacity of key regulatory departments and agencies that deal with major resource projects. This is a welcome initiative, and further progress toward consolidation and efficiency enhancement of the federal regulatory process should be sought.

A more fundamental criticism is that the outcomes of the energy project approval process are unpredictable. This reflects the lack of precision in guidelines, in particular regarding the integration of environmental considerations in the whole process, so that regional regulators have significant discretion as to the information they can request and their ultimate judgements. One way to improve licensing and approval procedures would be to reduce the number of approval bodies and phases. Ideally, investors should have access to "one-stop-shop" licensing, in which one official body holds as many of the approval responsibilities as possible or at least is given the duty to co-ordinate. Timelines for approval processes must also be clear and established in advance.

One other major uncertainty is linked to Aboriginal land claims, in particular in provinces like British Columbia where no settlement treaty has been signed between the federal government and the Aboriginal communities. Two landmark 2004 Supreme Court decisions have ruled that the government has a moral and legal obligation to conduct meaningful consultations when industrial development is proposed for Aboriginal land whose title is in dispute. Since then, Aboriginal consultations have delayed several huge energy projects. ${ }^{37}$ The diversity of the Aboriginal population makes it difficult to streamline the process and increase its predictability. Still, further effort should be made by the federal government to improve the consultation process.

36. Indeed, overlaps between provincial and federal regulations lengthen the regulatory approval process and increase the development costs of the uranium industry in Saskatchewan (Government of Saskatchewan, 2007). A large number of regulators are also involved in liquefied natural gas (LNG) development projects in the Atlantic Provinces, and there is a lack of clarity regarding jurisdictional authorities and construction and safety standards for LNG terminals (Tu Weissenberger, 2006).

37. A 1 150-kilometre oil-sands pipeline called Gateway, proposed by Enbridge Inc., to connect Edmonton with the west coast of British Columbia for export to China, has been shelved for several years in part because of concerns over Aboriginal rights and unsettled land claims. The 1200 kilometre Mackenzie Valley pipeline was dogged in 2004 and 2005 by two lawsuits against the government from the Dehcho First Nations, who said they had been unfairly excluded from the review process. The issues have still not been resolved. 


\section{Conclusion and policy recommendations}

This paper has examined ways of ensuring a sustainable development of the energy sector over the medium and longer term. Policy recommendations are provided below (Box 5).

\section{Box 5. Policy recommendations for energy and environmental policies}

\section{Management of scarce resources in the short and long term}

- $\quad$ Address labour shortages and infrastructure bottlenecks.

- Continue action to encourage participation of populations that are under-represented in the labour markets (in particular Aboriginals, women and the disabled) by providing further training support. Modify parameters of the Employment Insurance system to foster greater inter-provincial labour mobility.

- Assess whether the current use of public/ private partnerships by the federal and some provincial governments for some large-scale projects ensure efficient building and operation of infrastructure.

- Regularly review water pricing and rights to ensure efficient use of this increasingly scarce resource. In particular, check that the new Albertan water-allocation and licence-transfer processes reach their conservation objectives while minimising their effects on oil-sands developments.

- $\quad$ Adopt allocation and withdrawal rules for the Alberta Heritage Fund as Norway has done. Consider setting up a similar fund at the federal level to which windfall gains from the resource sector would be allocated.

\section{Effectiveness of environmental policies}

- Reduce investment risks by continuing to give firmer long-term direction on climate-change-abatement policies and by ensuring that environmental and energy policies are fully integrated.

- $\quad$ Continue to work towards a full set of federal-provincial equivalency agreements, but make sure the system is as harmonised as possible to limit transaction and monitoring costs. In particular, ensure that equivalency agreements do not prevent a future link of the Canadian emissions-trading systems with other international systems.

- Continue to make more use of market-instruments. Focus on the design of the planned national emissions-trading system, and ensure its compatibility with other markets in the United States and/or the European Union. Assess the pros and cons of the establishment of a hybrid model at the federal or the provincial level, whereby the permit price can fluctuate within a pre-defined corridor.

- Monitor emissions in the transport sector, and check that the setting of standards leads to significant emissions reductions. Consider the introduction of a (carbon) fuel tax in addition to standards.

- Consolidate the measures aimed at curbing energy demand and focus on those that are most cost-efficient.

\section{Energy mix}

- $\quad$ Liberalise electricity markets in provinces where they are still regulated. Liberalise trade in energy goods and services among provinces by finalising the energy chapter of the Agreement on Internal Trade.

- Investigate the efficiency of the current support provided to renewable energy and streamline its delivery. In particular, review the policy of promoting corn and cellulosic ethanol and other biofuels.

- Make regular assessments of policies that foster technology developments. Ensure that large firms get the appropriate share of support from Sustainable Development Technology Canada. 
ECO/WKP(2008)26

\section{Taxation and regulation}

- Regularly review the Alberta royalty regime. Continue the move toward the elimination of the preferential federal tax treatment for the mining sector. Re-examine the tax treatment of exploration and development costs as well as flow-through shares.

- $\quad$ Review the oil-sands tenure process regularly and remove the exploration/production requirement to make the system consistent with Alberta's sustainability objectives.

- $\quad$ Streamline and make the energy projects approval process more predictable. Improve the predictability of the process by setting up "one-stop-shop" licensing and timelines for approval processes at the provincial level. 
ECO/WKP(2008)26

\section{BIBLIOGRAPHY}

Alberta Environment (2006), Water Conservation and Allocation Guidelines for Oilfield Injection 2006, Edmonton.

Alberta Royalty Review Panel (2007), "Our Fair Share”, Report to the Ministry of Finance, September, Edmonton.

Athabasca Regional Issues Working Group (2005), "Wood Buffalo Business Case 2005: A Business Case for Government Investment in the Wood Buffalo Region's Infrastructure," RIWG, March, www.oilsands.cc/pdfs/Wood\%20Buffalo\%20Business\%20Case\%202005.pdf.

AXYS Environmental Consulting Ltd. and Lorrnel Consultants (2002), "Guidelines for the Implementation of Ecosystem Management Tools in the Athabasca Oil Sands Region", Prepared for the Management Tools Task Group, Landscape and Biodiversity Subgroup, Sustainable Ecosystem Working Group, Cumulative Environmental Management Association (CEMA), Calgary.

Baldwin, J., G. Gellatly and D. Sabourin (2006), Changes in Foreign Control under Different Regulatory Climates: Multinationals in Canada, Statistics Canada, March, Ottawa.

Bayoumi, T. and M. Mülheisen (2006), "Energy, the Exchange Rate and the Economy: Macroeconomic Benefits of Canada's Oil Sands Production", IMF Working Paper 06/70, March, Washington, D.C.

Blanchard, O. and J.F. Perkaus (2004), "Does the Bush Administration's Climate Policy Mean Climate Protection?" Energy Policy, Vol. 32, No. 18, pp. 1993-98.

Bosetti. V., C. Carraro and E. Massetti (2008), "Banking Permits: Economic Efficiency and Distributional Effects", CESifo Working Paper series N. 2214, February.

Boyer, M. (2007), “Higher Electricity Prices Can Unleash the Value of Quebec's Energy Potential”, Montreal Economic Institute, April, Montreal.

Bramley, M. (2007), “Analysis of the Government of Canada's April 2007 Greenhouse Gas Policy Announcement", The Pembina Institute, 28 May, Calgary.

Canadian Association of Petroleum Producers (2006), 2006-2020 Canadian Crude Oil Production and Supply Forecasts, Calgary.

Canadian Association of Petroleum Producers (2007a), Crude oil forecasts, markets and pipeline expansion, Calgary, June.

Canadian Association of Petroleum Producers (2007b), Oil Sands, May, Calgary.

Carrier, M. and J. Turcotte (2006), "The Contribution of the Energy Sector to the Canadian Economy", Analytical Note, Economic and Fiscal Policy Branch, Department of Finance Canada, Ottawa.

CERI (2006), Economic Impact of Alberta's Oil Sands in the Short Term, December, Calgary. 


\section{ECO/WKP(2008)26}

Clark, C.R. and A. Leach (2007), "The Potential for Electricity Market Restructuring in Quebec", Canadian Public Policy, Vol. XXXIII, No. 1.

Conference Board of Canada (2006), Death by a Thousand Paper Cuts, May, Ottawa.

Conference Board of Canada (2007), Canada's Energy Future: An Integrated Path, June, Ottawa.

Congressional Budget Office (2007), "The Potential for Carbon Sequestration in the United States", CBO Paper, September, Washington, D.C.

Construction Sector Council (2007), Construction Looking Forward, Labour requirements from 2007 to 2015 for Alberta, May, Ottawa.

Council of the Federation (2007), Climate Change Leading Practices by Provincial and Territorial Governments in Canada, August, Ottawa.

Cross, P. (2006), “The Year in Review: the Revenge of the Old Economy”, Canadian Economic Observer, Vol. 19, No. 4, April, Gatineau.

Davis, J., R. Ossowski, J. Daniel and S. Barnett (2001), "Stabilization and Savings Funds for Nonrenewable Resources: Experience and Fiscal Policy Implications", in J. Davis, R. Ossowki and A. Fedelino (eds.), Fiscal Policy Formulation and Implementation in Oil-Producing Countries, International Monetary Fund, Washington, D.C.

Doornbusch, R. and R. Steenblik, (2007), "Biofuels: Is the Cure Worse than the Disease?" paper prepared for the OECD Round Table on Sustainable Development, September, Paris.

Ellerman, D. (2000), "Tradable Permits for Greenhouse Gas Emissions: A primer with particular reference to Europe", MIT Joint Program on the Science and Policy of Global Change, Report No. 69, November, Cambridge MA.

Environment Canada (2007a), National Inventory Report, 1996-2005, Greenhouse Gas Sources and Sinks in Canada, April, Gatineau.

Environment Canada (2007b), The Cost of Bill C-288 to Canadian Families and Businesses, May, Gatineau.

Fullerton, D. and S. West (2000), “Tax and Subsidies Combinations for the Control of Car Pollution”, NBER Working Paper 7774, July.

Gianella, C. (2006),"A golden rule for Russia? How a rule-based fiscal policy can allow a smooth adjustment to the new terms of trade", OECD Economics Department Working Paper, No. 537, January, OECD Publishing, Paris.

Government of Alberta (2006a), Oil Sands Consultation Multi-stakeholder Committee Interim Report, November, Edmonton.

Government of Alberta (2006b), Alberta's Occupational Demand and Supply Outlook 2006-2016, November, Edmonton.

Government of Alberta (2007), The New Royalty Framework, October, Edmonton.

Government of Canada (2007a), Turning the Corner: A Plan to Reduce Greenhouse Gases and Air Pollution, April, Ottawa, www.ec.gc.ca/doc/media/m_124/agir-action_eng.htm 
Government of Canada (2007b), Mobilizing Science and Technology to Canada's Advantage, June, Ottawa.

Government of Canada (2008),Turning the Corner: Taking Action to Fight Climate Change, March, Ottawa, www.ec.gc.ca/doc/virage-corner/2008-03.

Government of Saskatchewan (2007), "Costs of regulatory delay", Presentation for the Inter-governmental Working Group Regulatory Reform Workshop, 8-9 March.

Griffiths, M., A. Taylor and D. Woynillowicz (2006), Troubled Waters, Troubling Trends, Pembina Institute, May, Drayton Valley, Alberta.

Hartzog, A. (2002), "The Alaska Permanent Fund: A Model of Resource Rents for Public Investment and Citizen Dividends", Geophilos, Spring, Scotland, USA.

Holden, M. (2006), "Canadian Oil Exports to the United States Under NAFTA", In Brief, Parliamentary Information and Research Service of the Library of Parliament, November, Ottawa.

Holroyd, P., S. Dyer and D. Woynillowicz (2007), "Haste Makes Waste: The Need for a New Oil Sands Tenure Regime", Oil Sands Issue Paper, No. 4, Pembina Institute, April, Calgary.

Holt, D. and A. Goldbloom (2007), "Housing affordability", Royal Bank of Canada Research Note, June.

Hydro-Quebec (2006), “Comparison of Electricity Prices in Major North American Cities”, fourth quarter, Montreal.

IEA (2007a), World Energy Outlook 2007: China and India Insights, Chapter 4, OECD Publishing, Paris.

IEA (2007b), Tackling Investment Challenges in Power Generation in IEA countries, Energy Market Experience, OECD Publishing, Paris.

Jaccard, M. (2007), Cost Curves for Greenhouse Gas Emission Reduction in Canada: The Kyoto Period and Beyond, MKJA Associates Inc; January, Vancouver.

Jaccard, M. and N. Rivers (2007), "Estimating the Effect of the Canadian Government's 2006-2007 Greenhouse Gas Policies", CD Howe Institute Working Paper, June, Toronto.

Jaccard, M., N. Rivers, C. Bataille, R. Murphy, J. Nyboer and B. Sadownik (2006), "Burning our Money to Warm the Planet: Canada's Ineffective Efforts to Reduce Greenhouse Gas Emissions", C.D. Howe Institute Commentary, 234, Toronto.

Kneebone, R. (2006), "The Feasibility of a 50\% Savings Rule for Alberta" in R. Gibbons and R. Roach (eds.), Seizing Today and Tomorrow: An Investment Strategy for Alberta's Future, Canada West Foundation, Calgary.

Kongsrud, P.-M. and I. Wanner (2005), "The Impact of Structural Policies on Trade-related Adjustment and the Shift to Services", OECD Economics Department Working Paper, No. 427, April.

Natural Resources Canada (2006), Audit of the Wind Power Production Incentive Program (WPPI), Ottawa, June.

NEB (2006), Canada's Oil Sands: Opportunity and Challenges to 2015: an Update, June, Calgary.

North America Energy Working Group (2005), "North American Natural Gas Vision,” NAEWG, January, www.pi.energy.gov/documents/NAEWGGasVision2005.pdf. 
NRTEE (2008), Getting to 2050: Canada's Transition to a Low-Emission Future, January, Ottawa.

OECD (2003), Voluntary Approaches for Environmental Policy: Effectiveness, Efficiency, and Usage in the Policy Mix, Paris.

OECD (2006a), The Political Economy of Environmentally Related Taxes, OECD Publishing, Paris.

OECD (2006b), OECD Economic Surveys: Canada, OECD Publishing, Paris.

OECD (2007), Infrastructure to 2030 (Vol. 2): Mapping Policy for Electricity, Water and Transport, OECD Publishing, Paris.

OECD (2008a), "Public-Private Partnerships: In Pursuit of Risk Sharing and Value for Money" internal working document, GOV/PGC/SBO(2008)1/REV1, 25 March, OECD, Paris.

OECD (2008b), OECD Economic Surveys: Canada, OECD Publishing, Paris.

Office of the Auditor General (2006), Report of the Commissioner of the Environment and Sustainable Development to the House of Commons, September, Ottawa.

Parkland Institute (2007), The Spoils of the Boom: Income, Profit and Poverty in Alberta, University of Alberta, June, Edmonton.

Philibert, C. et al (2003), "Evolution of Mitigation Commitments: Some Key Issues", internal working document, COM/ENVIRONMENT/EPOCH/IEA/SLT(2003)3, Paris.

Philibert, C. and J. Reinaud (2004), "Emissions Trading: Taking Stock and Looking Forward", internal working document, COM/ENV/EPOC/IEA/STL(2004)3, OECD, Paris.

Rivers, N., M. Jaccard and D. Sawyer (2008), "Pricing Carbon: Saving Green. A Carbon Price to Lower Emissions, Taxes and Barriers to Green Technology", David Suzuki Foundation, February.

Roberts, M. J. and M. Spence (1976), "Effluent Charges and Licenses under Uncertainty", Journal of Public Economics, Vol. 5, pp. 193-208.

Shabsigh, G. and N. Ilahi (2007), "Looking Beyond the Fiscal: Do Oil Funds Bring Macroeconomic Stabilisation?" IMF Working Paper, No. 07/96, Washington, D.C.

Statistics Canada (2007), "Households and the Environment Survey 2006”, The Daily, 11 July, Ottawa.

Tu Weissenberger, A. (2006), "Casting a cold eye on LNG: the real possibility and pitfalls for Atlantic Canada", The AIMS Oil and Gas Paper, No. 4, January, Halifax.

Urquhart, J. (2007), "Much Assumed in Plan to Close Coal-fired Plants", The Star, 20 June.

Van Audenrode, M., A. Fournier, N. Havet, and J. Royer (2005), Employment Insurance in Canada and International Comparisons, July, Ottawa.

World Resources Institute (2006), An Analysis of Greenhouse Gas Intensity Targets, Washington D.C., pdf.wri.org/target_intensity.pdf. 
ECO/WKP(2008)26

\section{WORKING PAPERS}

The full series of Economics Department Working Papers can be consulted at www.oecd.org/eco/Working_Papers/

617. The Dutch tax-benefit system and life-cycle employment. Outcomes and reform options (June 2008) Ekkehard Ernst and Timo Teuber

616. Regulation, Allocative Efficiency and Productivity in OECD Countries: Industry and Firm-Level Evidence (May 2008) G. Nicoletti, S. Scarpetta \& J.

615. Public social spending in Korea in the context of rapid population ageing (May 2008) Randall S. Jones

614. Enhancing the globalisation of Korea

(May 2008) Randall S. Jones and Taesik Yoon

613. Reforming housing and regional policies in Korea

(May 2008) Randall S. Jones and Tadashi Yokoyama

612. Moving towards more sustainable healthcare financing in Germany (May 2008) N. Brandt

611. Improving education outcomes in Germany (May 2008) David Carey

610. Have developed countries escaped the curse of distance? (May 2008) Hervé Boulhol and Alain de Serres

609. Measures of international transport cost for OECD countries (April 2008) Stephen S. Golub and Brian Tomasik

608. Encouraging labour force participation in Chile (April 2008) D. Contreras, L. de Mello and E. Puentes

607. Tackling business and labour informality in Chile (April 2008) D. Contreras, L. de Mello and E. Puentes

606. Delivery cost-efficient public services in health care, education and housing in Chile (April 2008) D. Contreras, L. de Mello and E. Puentes

605. Managing Chile's macroeconomy during and after the copper price boom (April 2008) Luiz de Mello

604. Avoiding the value added tax: Theory and cross-country evidence (April 2008) Luiz de Mello

603. Oil Price Shocks, Rigidities and the Conduct of Monetary Policy: Some Lessons from a New Keynesian Perspective (April 2008) Romain Duval and Lukas Vogel 
602. The Contribution of Economic Geography to GDP Per Capita (April 2008) Hervé Boulhol, Alain de Serres and Margit Molnar

601. Estimating a supply block for Poland (April 2008) Rafal Kierzenkowski, Patric Ollivaud, Franck Sédillot and Philippe Briard

600. Product market regulation and economic performance across Indian states (March 2008) Paul Conway, Richard Herd and Thomas Chalaux

599. Improving product market regulation in India: an international and cross-state comparison (March 2008) Paul Conway and Richard Herd

598. Revenue buoyancy and its fiscal policy implications (February 2008) Isabelle Joumard and Christophe André

597. Monetary policy, market excesses and financial turmoil (February 2008) Rudiger Ahrend, Boris Cournède and Robert Price

596. Explaining differences in hours worked among OECD countries: an empirical analysis (February 2008) Sven Blondal and Jean-Marc Burniaux

595. Fiscal policy in India: past reforms and future challenges (February 2008) Richard Herd and Willi Leibfritz

594. The significance of Switzerland's enormous current-account surplus (March 2008) Peter Jarrett and Céline Letremy

593. Interdependencies between monetary policy and foreign-exchange intervention under inflation targeting: the case of Brazil and the Czech Republic (January 2008) Jean-Yves Gnabo, Luiz de Mello and Diego Moccero

592. Solow or Lucas? Testing growth models using panel data from OECD countries (December 2007) Jens Arnold, Andrea Bassanini and Stefano Scarpetta

591. The private internal rates of return to tertiary education: new estimates for 21 OECD countries (December 2007) Romina Boarini and Hubert Strauss.

590. Making federalism work (December 2007) Alexandra Bibbee

589. The wage premium on tertiary education: New estimates for 21 OECD countries (December 2007) Hubert Strauss and Christine de la Maisonneuve

588. Enhancing the benefits of financial liberalisation (March 2007) Stefan Ide, Jens Høj and Patrick Lenain

587. Improving incentives in tertiary education (March 2007) Jens Høj 